\title{
Değerler Eğitiminde Video Blog Kullanımı
}

\section{Usage of Video Blog in Values Education}

\author{
Ozan COŞKUNSERÇE, Sorumlu Yazar, Dr. Öğr. Üyesi. \\ Nevşehir Hacı Bektaş Veli Üniversitesi, Eğitim Fakültesi, Nevşehir/Türkiye. \\ coskunserce@nevsehir.edu.tr \\ https://orcid.org/0000-0002-1230-324X
}

ISSN: 1303-880X

e-ISSN: 2667-7504

http://ded.dem.org.tr

Makale Türü / Article Type:

Araştırma Makalesi / Research Article

Geliş Tarihi / Received Date: 09.07.2020

Kabul Tarihi / Accepted Date: 29.10. 2020

Yayın Tarihi / Published Date: 25.12.2020

Tr/En: $\operatorname{Tr}$

Intihal / Plagiarism: Bu makale, en az iki hakem tarafindan incelendi ve intihal içermediği teyit edildi. / This article has been reviewed by at least two referees and scanned via a plagiarism software.

Attf/Citation: Coşkunserçe, O. (2020). Değerler eğitiminde video blog kullanımı. Değerler Ĕ̈itimi Dergisi, 18 (40), s.307-343.

https://doi.org/10.34234/ded.767347 
Öz: Bu çalışmada, karakter ve değerler eğitimi (KDE) dersinde gerçekleştirilen video blog uygulamalarının öğretmen adaylarının değer eğitimine yönelik tutumları üzerindeki etkisini ve öğretmen adaylarının bu uygulamalar hakkındaki görüşlerini belirlemek amaçlanmıştır. Çalışmada karma araştırma yöntemi kullanılmıştır. Çalışmanın nicel boyutunu öntest-sontest kontrol gruplu deneysel desen oluşturmaktadır. Çalışmada nicel veri toplama amacı ile Değer Eğitimine Yönelik Tutum (DET) Ölçeği kontrol ve deney gruplarına derslerin başlangıcında ve sonunda, öntest ve sontest olarak uygulanmıştır. Çalışmanın nitel boyutunu ise video blog uygulamalarına katılan olan 11 öğretmen aday1 ile yapılmış olan yarı yapılandırılmış görüşmeler oluşturmaktadır. Deney grubu ile yürütülen ders sürecinde normal ders içeriğine ek olarak video blog uygulamaları gerçekleştirilmiştir. Video blog uygulamalarında, blog üzerinde örnek olay videoları paylaşılmış, öğretmen adaylarının bunları ders saatleri dışında izleyerek yorumlamaları istenmiştir. Analizler sonucunda, grupların değerler eğitimine yönelik tutumları arasında deney grubu lehine anlamlı bir fark olduğu belirlenmiştir. Ayrıca, deney grubu öğretmen adaylarının DET ölçeğinin faktörleri olan "değerler eğitiminin gereğine inanç", "değer eğitimini içselleştirme" ve "değer eğitimine yönelik olumsuz inanç" faktörlerinden aldıkları öntest ve sontest puanlarında sontest puanları lehine anlamlı bir fark olduğu görülmüştür. Bunun dışında öğretmen adayları video blog uygulamalarının KDE derslerini daha akılda kalıcı ve ilgi çekici hale getirdiği, öğrencilerin derse katılımını kolaylaştırdığı yönünde yorumlarda bulunmuştur.

Anahtar Kelimeler: Değerler eğitimi, Video blog, Örnek olay videoları, Tutum, Öğretmen adayları.

$\&$

Abstract: In this study was aimed to determine the effects of video blog activities performed in Character and Value Education (CVE) lesson on the attitudes of prospective teachers towards value education and their opinions regarding these activities. Mixed research method was used in the study. In the quantitative dimension of the study, experimental design with pretest-posttest control group was used. In order to collect quantitative data in the study, Attitude towards Value Education (AVE) Scale was applied to the control and experimental groups at the beginning and end of the lessons as pretest and posttest. The qualitative dimension of the study consists of semi-structured interviews with 11 prospective teachers participating in video blog activities. In the courses conducted with the experimental group, video blog activities were carried out during 
the regular class time in addition to the normal course content. In video blog activities, case study videos were shared on the blog, and prospective teachers were asked to watch and interpret them outside of class hours. As a result of the analyzes, it was determined that there was a significant difference between the attitudes of the groups towards values education in favor of the experimental group. In addition, it was observed that there was a significant difference in favor of posttest scores in the pre-test and posttest scores of the experimental group teacher candidates according to the factors of the AVE scale, "belief in the need for values education", "internalize value education" and "negative belief in value education" factors. Moreover, prospective teachers commented that video blog applications make CVE lessons more memorable and interesting, and facilitate students' participation.

Keywords: Values education, Video blog, Case study videos, Attitude, Prospective teachers.

(The Extended Abstract is at the end of the article)

\section{Giriş}

Öğrencilerin akademik bilgi düzeylerini arttırmak ve öğrencilere yeni beceriler kazandırmanın yanında, değerler eğitimi de eğitimin temel hedefleri arasında yer almaktadır. Çünkü bir toplumun bir arada yaşayabilmesini sağlayan ve toplumdaki bireyleri birbirine bağlayan önemli etmenlerden biri de değerlerdir. Değerler, bir kişinin veya başka bir sosyal varlığın yaşamında yol gösterici ilkeler olarak hizmet eden, önemi değişen, ilgili durumlar ötesinde arzu edilen hedefler olarak tanımlanabilir (Schwartz, 1994). Değerler doğuştan kazanılan olgular değillerdir, yaşantılar ile kazanılırlar. Bu nedenle değerlerin kazanımı eğitim süreçleri kapsamındadır. Değerler eğitimine ihtiyaç duyulmasına neden olarak toplumsal şiddetin ve ahlaki yozlaşmanın artması; ahlaki değerlere, nezaket kurallarına ve temizlik kurallarına uymama başlıkları gösterilmektedir (Aydın, 2017). Sağlıklı bir toplum yapısı için değerler eğitiminin önemi çok sayıda çalışmada vurgulanmaktadır (Fidan, 2017; Özdaş, 2013).

Amaç, içerik, öğretim ilke, yöntem, strateji ve ölçme yönleri açısından değerler eğitimi karmaşı ve zor bir süreç olarak görülmektedir (Ersoy \& Ünüvar, 2019). Ayrıca değerler eğitiminin soyut kavramlardan oluşan bir yapı olması nedeni ile öğrencilerin bu eğitimi içselleştirmede zorlandığı belirtilmektedir (Turan \& Ulusoy, 2015). Değeler eğitimi alanında yapılacak etkinliklerin soyut 
olan kavramları somutlaştıracak ve öğrencilerin bu kavramları içselleştirmesini kolaylaştıracak nitelikte olması beklenmektedir. Değerler eğitiminde sadece bilgi, kavram, beceri ve metotların öğretilmesi yeterli gelmemekte, ilgili değerlerin benimsenmesi ve davranışa dönüştürülmesi için değerler eğitiminin etkinlik temelli olarak uygulanması gerekmektedir (Aktepe \& Tahiroğlu, 2016). $\mathrm{Bu}$ nedenle öğretmenlerin sınıf içinde ve dışında değerler eğitiminin içselleştirilmesini kolaylaştıracak değişik uygulamalar yaptırması önemlidir (Memiş \& Gedik, 2010). Değerler eğitimi sürecini yönetecek öğretmenlerin bu etkinlikleri düzenleyebilmek için gerekli donanıma sahip olması gerekmektedir (Yıldırım, 2009). Ancak alanyazında öğretmen adaylarının değerler ve değerler eğitimi konusunda yeterli eğitim almadıklarını ve gerekli bilgiye sahip olmadıklarını ortaya koyan çalışmalar bulunmaktadır (Fidan, 2009). Bu çalışma sonuçları dikkate alındığında, okullarda değerler eğitimi sürecinin etkili bir şekilde yürütülebilmesi için öğretmen adaylarına uzmanlar tarafindan geliştirilecek etkinlikleri uygulama becerisinin kazandırılması gerekliliği ortaya çıkmaktadır.

Ayrıca öğretmenlerin değerler eğitimi sürecinde lider-uygulayıcı, model olma ve rehberlik etme rollerini benimsemesi de beklenmektedir (Çelikkaya \& Filoğlu, 2014; Kuşdil \& Kağıtçıbaş1, 2000). Sinıfta öğrenci öğretmenin sözlerinden çok davranışlarından etkilenmektedir (Saban, 2000). Değerler eğitimi programları ile eğitim alan öğrencilerin, bu tür bir programla eğitim almayan öğrencilere göre değerlere ilişkin daha fazla olumlu nitelikte davranış sergilediği görülmektedir (İşcan, 2007). Bu nedenle öğretmen adaylarına değerler eğitiminin uygulanması üzerine verilecek eğitimlerde, değerler eğitiminin içselleştirilmesi ve değerler eğitimi hakkındaki tutumun olumlu yönde değiştirilmesi temel hedefler olarak belirlenmelidir.

Değerler eğitiminde sınıf dışı etkinliklerin yeterince gerçekleştirilememesi, değerler eğitiminde yaşanan temel sorunlar arasındadır (Güçlü, 2015). Günümüzde internet ve web teknolojileri sayesinde eğitim süreçleri sınıf dışına taşınabilmektedir. Web tabanlı eğitim, öğrencilerin akademik başarısına önemli ölçüde katkı sağlayabilmektedir (Erdemir \& İngeç, 2014; Baltacı \& Akpınar, 2011). Web üzerinden gerçekleştirilen eğitim etkinlikleri, öğrencilerin kendi zaman, yer ve hızlarıyla öğrenme olanağı verir (Sünbül, 2012). Değerler eğitiminin web teknolojileri kullanılarak sınıf dışına taşınması ve böylece değerler eğitimine yönelik etkinliklerin sınırlı ders saatleri dışında da gerçekleştirilmesi mümkündür. Ancak öncelikle web teknolojilerinin bütün öğretmenlerin kullanabileceği şekilde basitleştirilmesi ve öğretmenlere web teknolojileri 
kullanılarak değerler eğitimi etkinliklerinin gerçekleştirilmesi ile ilgili eğitim verilmesi ihtiyacı bulunmaktadır. Web 2.0, daha önceki web teknolojilerinden farklı olarak, bilginin sadece sunulmak yerine kullanıcılar tarafından üretilip geliştirildiği ve daha sonrasında kolaylıkla paylaşıldığı ortamların genel adı olarak tanımlanmaktadır (Yükseltürk \& Top, 2016). Web 2.0 teknolojileri arasında bloglar, kullanıcılara kolay bir şekilde web üzerinden içerik üretme ve sunma imkanı sağlaması açısından ön plana çıkmaktadır. Bloglar, sahibine hazır bir şablon üzerinden içerik paylaşma imkanı sunan, paylaşımların tarihine göre s1ralandığı, en güncel paylaşımın en üstte gösterildiği web siteleridir. Bloglar, bu özellikleri nedeni bazı kullanıcılar tarafından günlük olarak kullanılabilmektedir. Blog kullanıcıları, blog üzerinde hesap açtıktan sonra paylaşımların altında yer alan yorum ekle seçeneği ile paylaşımlar hakkındaki düşüncelerini ve sorularını ekleyebilirler. Blogların, veri paylaşımı, işbirliği ve tartışma gibi etkinlikler düzenlenebilecek bir iletişim ve etkileşim ortamı olması nedeni ile öğretim ortamlarını destekleme amacı ile kullanılabilmektedir (Karger \& Quan, 2005). Bloglar, öğretmenlere kullanıcı dostu bir çevrimiçi ortam sağlayarak, yeni kavram ve konuların tanıtımı, sınıfta görüşülen önemli konuların tekrarı, testler ile öğrenmenin izlenmesi ve farklı stratejiler ile öğrenme ortamının zenginleştirilmesi gibi uygulamaların yapılmasını mümkün kılmakta, öğretim süreçlerini ders dışına taşıyarak öğretmenlere ek zaman kazandırmaktadır (Colombo \& Colombo, 2007).

Değer eğitiminde örnek olaylar ve kazandırılacak değerlerle ilgili filmlerin kullanıldığ1 etkinliklere yer verilmesi, soyut kavram olan değerleri somutlaştırılarak kazanımını kolaylaştırmaktadır (Turan \& Ulusoy, 2015). Değerler eğitiminde kullanılabilecek örnek olay videolarının web üzerinde kolay bir şekilde paylaşmı için video bloglar kullanılabilmektedir. Blog kelimesinde üretilmiş olan video bloglar, düzenli olarak yapılan paylaşımlarda video veya açıklayıcı metin, resim veya diğer metadata ile birlikte bir video bağlantısı içeren blog türüdür (Gao vd., 2010). Bloglardan temel farkı, yapılan paylaşımların video içerikli olmasıdır. Bloglar üzerinde paylaşılacak videolar çoğunlukla önce bir video portalına yüklenmekte ve daha sonra portal tarafından sağlanan bağlantı video blog üzerine eklenerek yeni bir video blog paylaşımı oluşturulmaktadır. $\mathrm{Bu}$ video portallarından en bilineni olan Youtube, aynı zamanda bir video blog olarak ta kullanılabilmektedir.

Video bloglar, kullanıcılara paylaşımlar üzerine görüş belirtme ve tartışma olanağı sunması nedeni ile değerler eğitiminde değer analizi yaklaşımının kul- 
lanımı için uygun bir araçtır. Değer analizi yaklaşımı, öğrencileri değerleri neden önemsemesi ve değerleri yaşantısına dahil etmesi gerektiği konusunda ikna etmekte etkilidir (Akbaş, 2008). Değer analizi yaklaşımında örnek olay yöntemi kullanılabilmektedir (Ersoy \& Ünüvar, 2019). Değer analizi yaklaşımında örnek olayların kullanımı ile öğrenciler örnek olaylardan hareket ederek ahlaki düşünme becerisi kazanmaktadır (Ryan, 1991). Değer analizi yaklaşımının video bloglarda uygulanmasında, video blogda kazandırılmak istenen değer üzerine bir örnek olay videosu paylaşılır ve öğrencilerin videoyu izlemesi istenir. Daha sonra öğrenciler, video üzerine öğretmen tarafından yöneltilen soruları yorum bölümünde cevaplar.

Video bloglar ile değerler eğitiminde birçok avantaj, imkân ve sorunlara çözüm olanağ sunan örnek olay videolarının ve web 2.0 teknolojilerinin birlikte kullanımı mümkündür. Değerler eğitiminde video blog etkinliklerinin gerçekleştirilmesi ile değerler eğitimi etkinliklerinin yer ve zamandan bağımsız olarak sınıf dışında gerçekleştirilmesi ve örnek olay videoları ile örnek olay incelemesi yönteminin kullanımı mümkün olmaktadır. Ayrıca, video blog üzerindeki paylaşımlara öğrencilerin yorum ekleyebilmeleri özelliği sayesinde değer analizi yaklaşımı kullanılabilmektedir. Ancak öncelikle örnek olay videolarının üretiminin ve öğretmen adaylarına yöntemin değerler eğitiminde kullanımının açıklanması gerekmektedir. Değerler eğitimine yönelik bu etkinliğin tanıtılması ile öğretmen adaylarının değerler eğitimine yönelik istek ve bakış açılarında olumlu yönde değişim olması beklenmektedir. Bu bağlamda bu çalışmanın amacı, karakter ve değerler eğitimi (KDE) dersinde gerçekleştirilen video blog etkinliklerinin öğretmen adaylarının değerler eğitimine yönelik tutumlarına etkisini ve öğretmen adaylarının etkinlikler hakkındaki görüşlerini belirlemektir.

\section{İlgili Alanyazın}

Blogların, öğretmen adaylarının eğitimine yönelik bir dersi destekleme amacı ile kullanımında, özellikle deneyimlerin kaydının alınması ve paylaşılması için kullanılması önerilmektedir (Divitini vd., 2005). Derslerde blog kullanımının öğretmen adaylarının sınıf topluluğu duygusunu güçlendirdiği belirlenmiştir (Atıcı \& Özmen, 2011). Blogların yüzyüze öğretim ile beraber kullanımında öğrencilerin yansitıcı düşünme ve konuyu anlama becerilerinde artış olduğu (Halic vd., 2010), sınıfta öğrendiği konular hakkındaki bilgisini arttırdığı ve fikirlerini başkalarıyla daha rahat paylaştı̆̆ı (Mansor, 2011) belirlenmiştir. Farklı gruplarla yapılan çalışmalarda sınıf bloglarının öğrenmeyi geliştirdiğine ilişkin 
benzer sonuçlara ulaş1lmıştır (Tang \& Lam, 2014; Ching, 2012). Sadece blog üzerinden yürütülen çevrimiçi derslerde ise öğretmen ve öğrencilerin birebir etkileşimde bulunmasının öğrenme performansını olumlu etkilediği belirlenmiştir (Yang vd., 2016). Öğretmen adaylarıyla yapılan çalışmalarda ise, öğretmen eğitiminde blogların kullanımının öğretmen adaylarının öğretmenlik becerilerinin geliştirdiği (Hramiak vd., 2009), öğretmenlik hakkında deneyim kazanmalarını sağladığı (Göktaş \& Demirel, 2012) ve öğretmen ile etkileşimi sağlayarak öğrenmelerine katkı sağladığı (Waely \& Aburezeq, 2013) belirlenmiştir.

Değerler eğitiminde blogların kullanımına ilişkin çalışmaya ulaşılamamış olmasına rağmen, farklı Web ve Bilgi ve İletişim Teknolojilerinin (BİT) kullanıldığı çalışmalar gerçekleştirilmiştir. Web tabanlı bir değerler eğitimi dersinin yürütülmesine ilişkin: hedeflerin açık olarak belirtilmesi, içeriğin çok dikkatli seçimi, sistemin arayüzünün kullanıcı dostu olması, öğretmen ve öğrenci arasında etkileşimin sağlanması ve değerlendirmenin tüm öğrenme sürecine yayılması gibi tavsiyelerde bulunulmuştur (Yu, 2011). BİT'in değerler eğitiminde kullanıldığı bir başka çalışmada, uygulamaya katılan öğrencilerin sosyal-kişisel değerler alanında daha fazla gelişme sergilediği görülmüştür (Rodriguez-Conde vd., 2011). Başka bir çalışmada, öğretmenlerin BİT’in kullanımına ilişkin yeterli bilgi ve deneyime sahibi olmamalarının, değerler eğitiminde BíT kullanımı alanında yaşanan en büyük eksiklik olduğu belirtilmiştir (Narinasamy \& Mamat, 2013).

Video blogların değerler eğitiminde kullanımına ilişkin herhangi bir çalışmaya ulaşılamamıştır ancak video blogların eğitsel amaçlarla kullanımında ise genellikle olumlu sonuçlara ulaşıldığı görülmektedir. Sınıf video bloglarının yüzyüze eğitim ile birlikte karma olarak kullanımının, öğrencilerin öğrenme performansları arttırdığı (Liu, 2016), İngilizce dersinde konuşma becerilerini geliştirdiği (Shih, 2010) sonuçlarına ulaşılmıştır. Video blogların İngilizce derslerine kullanımına ilişkin öğrenciler, bu yeni öğrenme aracına karşı olumlu tutum takınmış, zaman kısıtlamalarını kaldırarak daha esnek bir öğrenme ortamı sunduğunu belirtmişlerdir (Hung, 2011). Öğretmen adayları ile yapılan bir çalışmada ise, video blogların mesleki ve teknik anlamda yararlı olduğu ve bu bağlamda öğretmenlik mesleğiyle ilgili eksikleri görme, gözden geçirme ve düzeltme imkânı sağladığına ilişkin görüş bildirilmiştir (Fidan \& Debbağ, 2018). Öğretmen adaylarıyla yapılan diğer çalışmalarda video bloglar yansıtma ödevi (Kadjer \& Parkes, 2012) ve e-portfolyo (Parkes vd., 2013) hazırlama ve paylaşma amacı ile kullanılmıştır. Bu çalışmalarda video blogların kullanımı sonucunda öğretmen adaylarının düşünme becerilerinde artış olduğu gözlemlenmiştir. 
Videoların değerler eğitiminde kullanımına ilişkin yapılan bir çalışmada, içeriğin kısa videolar halinde ve müzik eşliğinde sunumu tavsiye edilmiş ve videoların değerler eğitimi konusunda çalışan öğretmen adaylarının içeriği daha kolay hatırlamasına yardımcı olduğu belirtilmiştir (Husin vd., 2019). Eğlence-eğitim videolarının değerler eğitiminde kullanıldığı bir başka çalışmada ise, bu tür videoların değerler eğitimini destekleme amacı ile kullanılabileceği açıklanmıştır (Dunlap, 2005). Youtube videolarının kullanıldığı bir başka çalışmada, ortaokul öğrencileri videoların değerleri özümsemelerine yardımcı olduğu yönünde görüş belirtmiştir (Lokman vd., 2018).

\section{Araştırmanın Amaci}

$\mathrm{Bu}$ araştırmanın amac1, KDE dersinde gerçekleştirilen video blog uygulamalarının öğretmen adaylarının değer eğitimine yönelik tutumları üzerindeki etkisini ve öğretmen adaylarının bu uygulamalar hakkındaki görüşlerini belirlemektir. $\mathrm{Bu}$ amaç doğrultusunda aşağıdaki araştırma sorularına yanıt aranmıştır:

- KDE dersinde video blog uygulamalarının gerçekleştirildiği deney grubu ile sadece dersin işlendiği kontrol grubunun değer eğitimine yönelik tutum puanları arasında anlamlı bir farklılık var midır?

- KDE dersinde video blog uygulamaları gerçekleştiren ve gerçekleştirmeyen öğretmen adaylarının, değer eğitiminin gereğine olan inanç bağlamıne da almış oldukları öntest ve sontest puanları arasında anlamlı bir fark var midir?

- KDE dersinde video blog uygulamaları gerçekleştiren ve gerçekleştirmeyen öğretmen adaylarının, değer eğitimini içselleştirme bağlamında almış oldukları öntest ve sontest puanları arasında anlamlı bir fark var mıdır?

- KDE dersinde video blog uygulamaları gerçekleştiren ve gerçekleştirmeyen öğretmen adaylarının, değer eğitimine yönelik olumsuz inanç bağlan mında almış oldukları öntest ve sontest puanları arasında anlamlı bir fark var midir?

- $\mathrm{KDE}$ dersinde gerçekleştirilen video blog uygulamaları hakkında öğretmen adaylarının görüşleri nedir? 


\section{Yöntem}

\section{Araştırma Modeli}

Çalışmanın nicel ve nitel araştırma yöntemlerinin kullanıldığı iki ayrı boyutu bulunmaktadır. Bu açıdan çalışmada karma araştırma yöntemi kullanılmıştır. Karma araştırma yönteminin en güçlü tarafı, nitel ve nicel paradigmanın beraber kullanılması neticesinde birinin eksik kaldığı noktada diğerinin bu eksikliği gidermesi ve araştırmada daha etkili sonuçlara ulaşılabilmesi olarak ifade edilmiştir (Kıral \& Kıral, 2011). Çalışmanın nicel boyutunda öntest-sontest kontrol gruplu deneysel desen kullanılmıştır. Deneysel desenler, değişkenler arasındaki neden sonuç ilişkilerini keşfetmeyi amaçlayan araştırma desenleridir (Büyüköztürk, 2016). Araştırmanın nitel boyutunda, incelenen konu hakkında daha derinlemesine veri toplama amacıyla öğretmen adayları ile yarı-yapılandırılmış görüşmeler gerçekleştirilmiştir.

\section{Çalışma Grubu}

Araştırmanın çalışma grubunu Nevşehir Hacı Bektaş Veli Üniversitesi (NHBVÜ) Eğitim Fakültesi Pedagojik Formasyon Sertifika Programı kapsamında KDE dersini alan öğretmen adayları oluşturmaktadır. Öğrencilerin tamamı NHBVÜ Fen Edebiyat Fakültesi Türk Dili ve Edebiyatı Lisans Programı dördüncü sınıf öğrencisidir. Uygulama 2018-2019 bahar ve 2019-2020 güz dönemlerinde iki ayrı ders grubu ile gerçekleştirilmiştir. Kontrol grubunu oluşturan 44 öğretmen adayının KDE dersi olağan süreci ile işlenirken, yine 44 öğretmen adayından oluşan deney grubunun KDE dersinde video blog etkinlikleri gerçekleştirilmiştir. Deney grubunda bulunan öğretmen adaylarının 25'i kız 19'u erkektir. Kontrol grubunda ise 23 kız ve 21 erkek bulunmaktadır. Yarı yapılandırılmış görüşmeleri gerçekleştirildiği 11 öğrencinin altısı kız, beşi erkektir.

\section{Video Blog Etkinlikleri}

Video Blog etkinlikleri iki temel aşamadan oluşmaktadır. Bu aşamalara aşağıda başlıklarda açıklanmıştır.

\section{Örnek olay videolarının hazırlanması}

Video blog uygulamasının gerçekleştirilebilmesi için, blog ortamında sunulacak örnek olay videolarına ihtiyaç duyulmaktadır. Bu amaçla hazırlanmış 
yeterli Türkçe içerik bulunmaması nedeni ile video blog uygulamasının yapı1dığı dönemden önceki iki ders döneminde, KDE dersi kapsamında örnek olay videoları hazırlanmıştır. Örnek olay videolarının hazırlana bilmesi için öğrenciler beşerli proje grupların ayrılmış ve Milli Eğitim Bakanlığı (MEB) Değerler Eğitimi Yönergesinde yer alan değerler listesini temel alarak videolarını geliştirmeleri istenmiştir. Video çekimlerinden önce öğrencilere video düzenleme yazılımları üzerine eğitim verilmiş ve videolarının senaryolarını hazırlamaları istenmiştir. Videoların tema olarak belirlenen değerin önemini yaşamın içinden seçilen örnek bir olay üzerinden vurgulaması istenmiş, hazırlanan senaryoların bu amaca olan uygunluğu dersin öğretim üyesi ile birlikte gözden geçirilmiştir.

Senaryoları onaylanan proje grupları video çekimlerini gerçekleştirmiş ve sonraki aşamada video düzenleme yazılımı ile projelerine son şeklini vermiştir. Son olarak sınıfta videolar izlenmiş, proje grubu, öğretim üyesi ve diğer öğrenciler video üzerinde tartışarak, örnek olayın tema olarak belirlenen değerin önemini ne derece yansıttığını değerlendirmiştir. Öğrencilerden videolarının eğitsel amaçlarla kullanımına ilişkin yazılı izinleri alınmıştır. Örnek olay videosu geliştirme uygulamasının yapıldığı iki dönemin sonunda geniş bir örnek olay video havuzu oluşturulmuştur. Aşağıda video blog uygulamasında kullanılan bazı örnek olay videolarından ekran görüntüleri sunulmuştur.
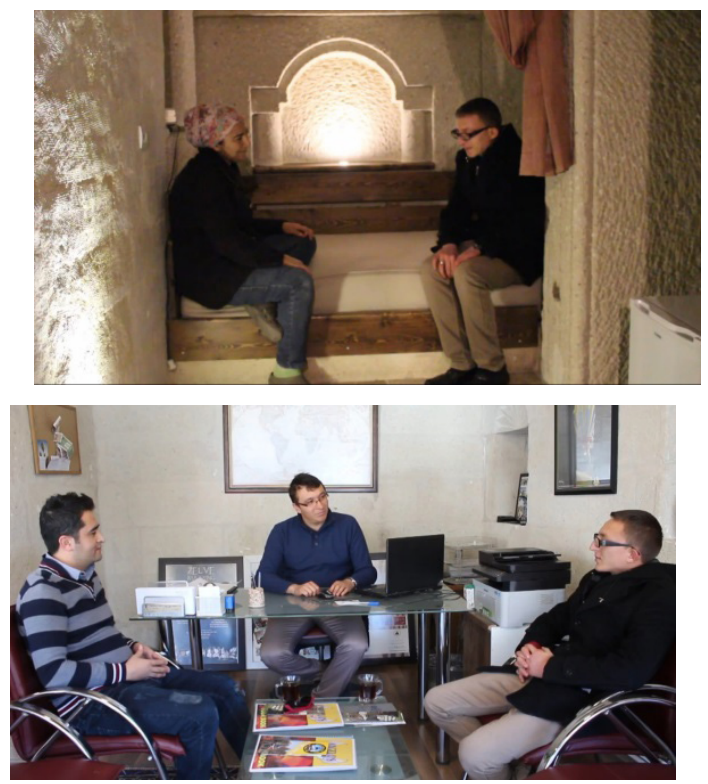


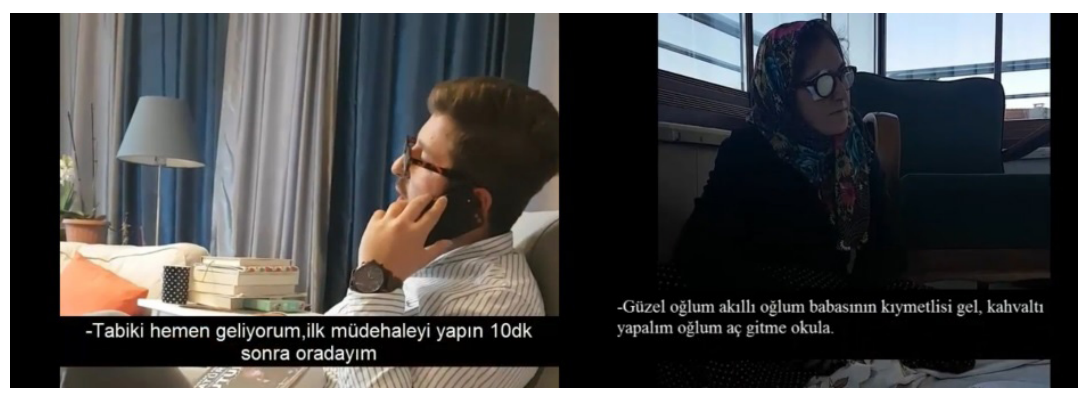

Şekil 1. Örnek Olay Videolarından Ekran Görüntüleri

\section{Video blog etkinlikleri}

Video blog etkinlikleri KDE dersini alan 44 öğrenci ile gerçekleştirilmiştir. Ders kapsamında açılan blog üzerinde, haftalık olarak paylaşımlar yapılmıştır. Paylaşımlarda o haftanın teması olarak belirlenen değer üzerine daha önce hazırlanmış olan örnek olay videosu bulunmaktadır. Derste blog sayfası ve yapılan paylaşımlar hakkında bilgi verilmiş, öğretmen adaylarının videoları izlemeleri ve videoların altına sorulan sorular doğrultusunda görüşlerini ve kendi analizlerini yazmaları istenmiştir. Böylece ders saatleri dışında "değer analizi yaklaşımı" ile "örnek olay incelemesi yönteminin" birlikte uygulanması mümkün olmuştur. Aşağıda Şekil 2'de öğrencilerin yaptıkları yorumlardan örnekler verilmiştir.

DÜRUSTLUKK

Hikâyenin ana fikri dürüst olanın kazanmasıdır. Ali'nin yaptığı davranış doğrudur. Uzun zamandır iş bulamamasına rağmen, işe girmek için dürüst olmaktan hiç vazgeçmemiştir. Annesi, oğlu için hiçbir zaman yanlış yönlendirme yapmamıș, oğlunun dürüstlükten, doğruluktan ayrılmaması için, hep telkinde bulunmuştur. Alinin doğru davranış sergilemesinde, annesinin bu davranışı çok etkilidir. İşverenin, dürüst olan Ali'yi seçmesi en doğru karardır. Ahmeți sadece bıraktığı cv ile değerlendirmiș olsaydı; dürüstlükten ayrılarak, yanlıș davranış sergilemiș olan Ahmet, kısa vadede kazanmış gibi görünecekti, Fakat ișin gerçek yüzü ortaya çıkınca ișverenin güvenini ve ișini kaybetmiș olacaktı. Ali ise dürüstlüğü sayesinde hem iş sahibi oldu, hem de ișverenin gūvenini kazanmıș oldu.

Dürüstlük, mesela temizlik gibi somut bir kavram olsaydı, çocuklara somut örneklere anlatımı daha kolay olabilirdi. Fakat dürüstlük soyut ve asında insanlık için çok temel bir konu olduğu için, uzun zamana yayılmalı, sabırla ve birçok kanaldan çocuklara aktarılmalı. Ilk ve en önemli aktarım bence, aile içinde her bireyin sadece büyüklere değil, çocuklara da dürüst olması. Ailenin çocuğa yalan konușmaması, verdiği sōzü mutlaka yerine getirmesi vs. gibi.

Okulda da bu böyle olmalı. Öğretmen önce çocuklara karșı kendisi dürüst olmalı. Sınıf içinde dürüstlük konusunda doğru davranış sergileyen çocuklara vurgu yapmalı, diğer arkadaşlarına anlatmalı. Dürüstlük konusunda yanlıș davranış sergileyen çocukları, rencide etmeden uyarmalı, her seferinde doğru davranışı anlatmalı. Bunu yaparken, bir çocuğun yanlış davranışını küçük görüp, görmezden gelmemeli. Yanlış davranıșa karșı iltimas gōstermemeli.

Etkinlik olarak; ben çocuklar için en faydalı bilgi aktarımının sözelden daha ziyade görsel iletişimle sağlandığını dūșūnüyorum. Bunun için sınıf içinde, drama etkinlikleri yapılabilir. Dürüstlük ile ilgili, çocukların kendilerinin katılıı̆ı, küçük küçük tiyatro gösterileri hazırlanabilir. Çocukların yaș grubuna göre, çizgi film ya da animasyon olabilir. Daha büyük yaș grupları için, netten videolar, çarpıcı slaytlar çocuklarla paylașılabilir. Görsel afișler sınıf duvarlarında olabilir.

Yanıtlayın Sil 
Ana fikri: insan sevdiği ōnem verdiği kişi için kendinden bile vazgeçebilir. Hikayedeki doğru /yanlış davranıșlar:annenin evladı için kendinden vazgeçmesi çocuğun agresif tavırlarına karșı ılımlı ve yumaşak olması çocuğun kendisine karșı yaptığı davranıșı anlamaya çalıșması çocuğunun psikolojisini dūșündüğũ için ona bu konuyu anlatmaması sürekli iletişim kurmaya çalıșması olumlu davranıșlar arasında yer alabilir çocuğun aile ve değerler kavramından haberdar olmaması bununla orantılı olarak annesine karşı șiddet içerikli ve küçümseyen davranışlar sergilemesi annesi de olsa giyimi fiziksel eksikliğinden dolayı onu yok sayması olumsuz davranıșlar arasında yer alıyor. Videonun vefayı anlatma bașarısı: orta düzeyde ve klişeydi. Nedeni bunun gibi olayların fazlaca görülmesi ve ișlenmesi farklı bir hikaye ile ele alınabilirdi. Vefa değerinin kazandırılması için kullanılabilecek bir ōrnek olay: Karlı bir kıș günüydü sis bulutundan göz gözü görmüyordu adeta yollar bulanmış arabalar buzlanmış yollarda kayıyordu. O sırada korna sesi ile irkildim. Arkamı döndüğürrde bir araba farının gözüme değdigine șahit oldum o anda bir el kolumdan tutup beni yolun kenarına itti o anda büyük bir sesle karșı karșıya kaldım bu ses bir çarpıșma sesiydi. Hızlı bir şekilde olduğum yerden kalkıp arabanın ışığına doğru ilerledim. 0 anda gördüklerim beni oldukça șasırtmıștı 40 yaşlarında bir adam yerde kanlar içerisinde yatıyordu. Şoförün yardımıyla hızıca hastaneye yetiștirdik yapılan tetkiklere göre sağ bacağını kullanamayacağını ōğrendik araba sağ bacağına büyük ölçüde zarar vermiști. Adamın yaptığı bu vefa yı belki de hayatım boyunca ödeyemeyecegimi anladım. Fakat bir nebze de olsa hayatına yapacağım dokunuşlarla bu borcu hafifletmek calıșacagım. Kısaca Bahçıvan bir gül için bin dikene su verir...

Yanıtlayın Sil

Şekil 2. Örnek Öğrenci Görüşleri

\section{Verilerin Toplanması}

Çalışmada nicel verilerin toplanması amacı ile Çetin (2018) tarafından hazırlanan "Değer Eğitimine Yönelik Tutum (DET) Ölçeği” kullanılmıştır. Ölçeğin amacı öğretmen adaylarının değer eğitimine yönelik tutumlarının belirlenmesi olarak açıklanmaktadır. Kontrol ve deney gruplarına KDE dersinin başında ve sonunda bu ölçek uygulanmıştır. Ölçek "değerler eğitiminin gereğine inanç", "değer eğitimini içselleştirme" ve "değer eğitimine yönelik olumsuz inanç" başlıkları altında üç alt faktör içermekte ve 31 maddeden oluşmaktadır. Maddelere verilen cevaplar ve puanlaması beşli likert tipindedir (1=hiç katılmıyorum, 2=katılmıyorum, 3=kısmen katılıyorum, 4=büyük ölçüde katılıyorum, 5=tamamen katılıyorum). Ölçeğin güvenirliği kontrol ve deney guruplarının öntest ve sontest verilerinin Cronbach Alpha değeri hesaplanarak incelenmiştir. Güvenilirlik katsayısının .70 ve üzerinde olması ölçek puanlarının güvenilirliği için yeterli bulunmaktadır (Büyüköztürk, 2008). Tablo 1 incelendiğinde elde edilen değerlerin kabul edilebilir aralıkta olduğu görülmektedir.

Tablo 1. Cronbach Alpha Kullanılarak Yapılan Güvenilirlik Analizi

\begin{tabular}{lll}
\hline & Öntest & Sontest \\
\hline Kontrol & .844 & .896 \\
\hline Deney & .885 & .780 \\
\hline
\end{tabular}


Çalışmanın nitel verileri video blog uygulamalarına katılmış olan 11 öğretmen adayı ile yapılmış olan yarı-yapılandırılmış görüşmeler ile toplanmıştır. Görüşmelerin temel amacı video blog uygulamaları hakkında öğretmen adaylarının görüşlerini toplamaktır. Kontrol grubunda bulunan öğretmen adaylarının, video blog etkinlikleri hakkında bilgisi ve deneyimi olmaması nedeni ile kontrol grubunda bulunan öğretmen adayları ile görüşme gerçekleştirilmemiştir. Görüşme formu 8 sorudan oluşmaktadır. Görüşme formu, araştırmanın soruları ve ilgili alanyazın temel alınarak hazırlanmıştır. Görüşmeleri gerçekleştirmeden önce iki alan ve bir dil uzmanının görüşleri alınarak forma son şekli verilmiştir. Görüşmelerin yarı yapılandırılmış yapıda olması nedeni ile görüşmelerde öğretmen adaylarına görüşme formundaki sorular dışında da sorular yöneltilmiştir.

\section{Verilerin Analizi}

Çalı̧̧manın nicel verilerinin analizinde SPSS 21 yazılımı kullanılmıştır. Verilerin analizinde kullanılacak uygun tekniğin seçimi için öncelikle DET ölçeğinden elde edilen puanların parametrik testlerin temel varsayımlarını karşılama durumları kontrol edilmiştir. Bu nedenle öncelikle verilerin normal dağılım durumları incelenmiştir. Verilerin normal dağılım varsayımın gerçekleşip gerçekleşmediğini belirlemek amacıyla için kontrol ve deney gruplarının aldıkları puanların çarpıklık (skewness) ve basıklık (kurtosis) değerleri hesaplanmıştır. Ayrıca değerlerin normallik sınaması için Shapiro-Wilk testine başvurulmuştur. Elde edilen veriler Tablo 2'de sunulmuştur.

\begin{tabular}{|c|c|c|c|c|}
\hline & & Çarpıklık & Basıklık & Shapiro-Wilks* \\
\hline \multirow{2}{*}{ Kontrol } & Öntest & .215 & -.628 & .710 \\
\hline & Sontest & .030 & -632 & .428 \\
\hline \multirow{2}{*}{ Deney } & Öntest & -.150 & 1.464 & .850 \\
\hline & Sontest & .203 & -.491 & .560 \\
\hline
\end{tabular}

${ }^{*} \mathrm{p}<.05$

Çarpıklık ve basıklık değerleri \pm 2.0 aralığında yer aldığında verilerin normal dağılım gösterdiği kabul edilebilmektedir (George \& Mallery, 2010). Tablo 2 incelendiğinde, tüm çarpıklık ve basıklık değerlerinin belirtilen aralıkta yer aldığ 1 , bu nedenle ölçekten elde edilen puanların normal dağılım açısından kabul edilebilir düzeyde olduğu söylenebilir. Ayrıca verilerin normal dağılım varsayımı Shapiro-Wilks testi ile de kontrol edilmiş, kontrol ve deney gruplarının öntest ve sontest puanlarının dağılımının bu anlamlılık düzeyinde $(p<.05)$ nor- 
mal dağılımdan anlamlı bir farklılık göstermediği sonucuna ulaşılmıştır. Ayrıca Levene's F testi ile vanyansların eşit olduğu görülmüştür.

Verilerin normal dağılım gösterdiğinin anlaşılması üzerine, DET ölçeğinden elde edilen öntest ve sontest puanları, ilişkisiz örneklemler t-testi ve ANCOVA ile analiz edilmiş, ölçeğin alt faktörlerinden alınan öntest ve sontest puanları ise bağımlı örneklem t-testi ile analiz edilmiştir. Yapılan tüm analizlerde anlamlılık düzeyi .05 olarak kabul edilmiştir.

Yarı-yapılandırılmış görüşmelerin analizinde ise içerik analizi yöntemine başvurulmuştur. Birbirine benzeyen verilerin belirli kavramlar ve temalar çevresinde toparlamak ve bunları okuyucunun rahat anlayabileceği bir şekilde sunmak içerik analizi kapsamında yapılan işlemdir (Yıldırım \& Şimşek, 2006). İçerik analizi araştırmacı ve bir uzman tarafından ayrı olarak gerçekleştirilmiş ve daha sonra iki analiz karşılaştırılarak analizin güvenilirliği test edilmiştir. Güvenirlik, Miles ve Huberman’ın (1994) formülü (güvenilirlik = görüş birliği / görüş birliği + görüş ayrılığı) formülü ile hesaplanmış ve \% 85 değerine ulaşılmıştır.

\section{Bulgular}

\section{Öğretmen Adaylarının DET Ölçeğinden Aldıkları Puanlara İlişkin Bulgular}

"KDE dersinde video blog uygulamalarının gerçekleştirildiği deney grubundaki öğretmen adayları ile geleneksel yöntemler ile dersin işlendiği kontrol grubundaki öğrencilerin değer eğitimine yönelik tutum puanları arasında anlamlı bir farklılık var mıdır?" araştırma sorusuna yanıt arama amacı ile DET ölçeğinden elde edilen veriler incelenmiştir.

Öncelikle, kontrol ve deney gruplarının öntest puanlarının anlamlı bir farklılık olup olmadığını test etmek amacı ile ilişkisiz örneklemler t-testi uygulanmıştır. Yapılan analizin sonuçları Tablo3'te sunulmuştur.

\begin{tabular}{llllllll}
\hline \multicolumn{6}{l}{ Tablo 3: Grupların DET Ölçeği Öntest Puanlarını İlişkisiz Örneklemler T-Testi Sonuçları } \\
\hline & $\mathbf{N}$ & $\overline{\mathbf{X}}$ & $\mathbf{S S}$ & $\mathbf{t}$ & $\mathbf{~ s d}$ & $\mathbf{p}$ & $\mathbf{d}$ \\
\hline Kontrol & 44 & 3.872 & 0.355 & \multirow{2}{*}{.492} & 86 & .624 & .103 \\
\hline Deney & 44 & 3.834 & 0.385 & & & & \\
\hline
\end{tabular}

Tablo 3 incelendiğinde kontrol ve deney gruplarının DET ölçeği öntest puanları arasında anlamlı bir farklılık olmadığ görülmektedir, $t_{(86)}=-.492, p=.624$, 
$d=.103$. Etki büyüklüğü ise küçük $(\mathrm{d}<.2)$ düzeydedir (Cohen, 1988). Bu durumda kontrol grubunun öntest puanı $(\bar{X}=3.872)$ ile deney grubunun $(\bar{X}=3.834)$ öntest puanlarının denk olduğu söylenebilir.

Kontrol ve deney gruplarının farklılaşıp farklılaşmadığına ilişin yapılacak veri analizlerinde, öntest puanlarının sontest puanlarındaki etkisini istatistiksel olarak kontrol altına alarak grupların düzeltilmiş sontest puanlarını karşılaştıran ANCOVA yaklaşımının kullanımı önerilmektedir (Büyüköztürk, 2016). Bunun için öncelikle ANCOVA'nın varsayımlarının yerine getirilme durumu kontrol edilmiştir.

ANCOVA'nın varsayımlarından ilki olan kontrol ve deney gruplarının sontest puanlarının normal dağılımı durumu daha önce test edilmiş ve varsayımın karşılandığına ilişkin veriler Tablo 2'de sunulmuştu. Varsayımlardan bir diğeri olan öntest-sontest puanları arasında doğrusal ilişki olması durumu da test edilmiş (kontrol grubu için $r=.483$, deney grubu için $r=.317$ ) ve her iki grup için de $\mathrm{r}>=0.3$ olması nedeni öntest-sontest puanları arasında doğrusal bir ilişki olduğu kabul edilmiştir (Büyüköztürk, 1998). Varyansların eşitliği varsayımı ise grup sayıları tam olarak eşit olduğunda atlanabilmektedir (Field \& Miles, 2010; Miles \& Banyard, 2007). Kontrol ve deney gruplarının sayılarının tam olarak eşit olması $(N=44)$ nedeni ile bu varsayım atlanmıştır. Son olarak grupların öntestte göre sontest puanlarının tahmininde kullanılacak regresyon doğrularının eğimleri kontrol edilmiştir. Yapılan "grup x öntest" ortak etki testi sonucunda, regresyon doğrularının eğimleri arasındaki farkın istatistiksel olarak anlamlı olmadığ 1 sonucuna ulaşılmışıtır $\left(F_{(1,84)=} 3.874, p=.052\right)$. Bütün varsayımların karşılanması üzerine yapılan ANCOVA'ya ilişkin veriler Tablo 4 ve Tablo 5 'te sunulmuştur.

Tablo 4: Grupların DET Ölçeği Öntest Puanlarına Göre Düzeltilmiş Sontest Puanlarının Kovaryans Analizi Sonuçları

\begin{tabular}{lllllll}
\hline Varyansın kaynağı & $\begin{array}{l}\text { Karelerin } \\
\text { toplamı }\end{array}$ & sd & $\begin{array}{l}\text { Karelerin } \\
\text { ortalaması }\end{array}$ & $\mathbf{F}$ & $\mathbf{p}$ & $\mathbf{\eta}^{2}$ \\
\hline Öntest(Regresyon) & 1.532 & 1 & 1.532 & 16.272 & .000 & .161 \\
\hline Grup & 3.832 & 1 & 3.832 & 40.708 & .000 & .324 \\
\hline Hata & 8.002 & 85 & .094 & & & \\
\hline
\end{tabular}

Toplam (Düzeltilmiş) $13.124 \quad 87$

Tablo 4'te görüldüğü gibi, yapılan ANCOVA sonucunda kontrol ve deney gruplarının DET ölçeği öntest puanlarına göre düzeltilmiş sontest puanları arasinda anlamlı bir farklılık olduğu bulunmuştur $(F(1,85)=40.708, p=.000)$. Bu 
bulgu uygulanan deneysel işlemin (öğretmen adaylarına değerler eğitiminde video blog kullanımı eğitimi verilmesi) öğrencilerin değerler eğitimine yönelik tutumlarında bir farklılığa yol açtığını göstermektedir.

Tablo 5: Grupların DET Ölçeği Sontest Puanları ve Öntest Puanlarına Göre Düzeltilmiş Sontest Puanlar1

\begin{tabular}{llllll}
\hline & \multicolumn{3}{l}{ Sontest } & & \multicolumn{2}{l}{ Düzeltilmiş Sontest } \\
\hline & $\mathrm{N}$ & $\overline{\mathrm{X}}$ & $\mathrm{sd}$ & $\overline{\mathrm{X}}$ & $\mathrm{sd}$ \\
\hline Kontrol & 44 & 3.994 & .402 & 3.987 & .046 \\
\hline Deney & 44 & 4.398 & .245 & 4.405 & .046 \\
\hline
\end{tabular}

Tablo 5’te görüldüğü gibi, öntestte göre düzeltilmiş sontest DET ölçeği pua$\mathrm{n} 1$ kontrol grubunun $\bar{X}=3.987$, deney grubunun $\bar{X}=4.405^{\prime}$ tir. Bu durumda KDE dersinde video blog kullanımı uygulaması yapan öğretmen adaylarının değerler eğitimine yönelik tutumları, geleneksel yöntemlerle dersi işleyenlere göre daha olumlu olduğu anlaşılmaktadır. Tablo 4'te etki büyüklüğü $\left(\eta^{2}\right)$ değerleri incelendiğinde ise, farklı işlem gruplarında olmanın, öntest puanlarından bağımsız olarak, DET ölçeği sontest puanlarındaki değişkenliğin \% 32.4'ünü açıkladığ1 görülmüştür. Bu durumda etki büyüklüğünün orta düzeyde olduğu söylenebilir.

\section{Öğretmen Adaylarının DET Ölçeğinin Faktörlerinden Aldıkları Pu- anlara İlişkin Bulgular}

\section{Değerler eğitiminin gereğine inanç faktöründen elde edilen bulgular}

Bu bölümde deney grubunu oluşturan öğretmen adaylarının, DET ölçeğinin ilk faktörü olan "Değer eğitiminin gereğine inanç" faktöründen almış oldukları öntest ve sontest puanları arasında anlamlı bir fark olup olmadığı incelenmiştir. $\mathrm{Bu}$ amaçla ilişkili örneklemler t-testi uygulanmıştır. Analizin sonuçları Tablo 6'da sunulmuştur.

\begin{tabular}{|c|c|c|c|c|c|c|c|c|c|}
\hline \multicolumn{10}{|c|}{$\begin{array}{l}\text { Tablo 6: Kontrol ve Deney Grubu Öğretmen Adaylarının, DET Ölçeği “Değer Eğitiminin Gereği- } \\
\text { ne İnanç” Faktöründen Almış Oldukları Öntest ve Sontest Puanlarının Bağımlı Örneklem T- Testi } \\
\text { Sonuçları }\end{array}$} \\
\hline Faktör & Grup & Test & $\mathrm{N}$ & $\overline{\mathrm{X}}$ & SS & t & sd & $\mathbf{p}$ & d \\
\hline \multirow{4}{*}{$\begin{array}{l}\text { Değerler eğitiminin } \\
\text { gereğine inanç }\end{array}$} & \multirow{2}{*}{ Kontrol } & Öntest & 44 & 3.848 & 0.404 & \multirow{2}{*}{-.238} & \multirow{2}{*}{43} & \multirow{2}{*}{.030} & \multirow{2}{*}{.406} \\
\hline & & Sontest & 44 & 4.021 & 0.446 & & & & \\
\hline & \multirow{2}{*}{ Deney } & Öntest & 44 & 3.920 & 0.464 & \multirow{2}{*}{-.500} & \multirow{2}{*}{43} & \multirow{2}{*}{.000} & \multirow{2}{*}{1.260} \\
\hline & & Sontest & 44 & 4.420 & 0.315 & & & & \\
\hline
\end{tabular}

Tablo 6 incelendiğinde, kontrol grubunun değerler eğitiminin gereğine inanç faktöründen aldığ 1 öntest ve sontest puanları arasında anlamlı bir farklılık olduğu görülmektedir, $t(43)=-2.820, p=.030, d=.406$. Kontrol grubuna dahil olan 
öğretmen adaylarının değerler eğitiminin gereğine inanç faktöründen aldıkları puanlar dersler öncesinde $\bar{X}=3.848$ iken, dersler sonucunda $\bar{X}=4.021$ 'e yükselmiştir. Etki büyüklüğ̈̈ ise orta düzeydedir $(\mathrm{d}<.5)$. Bu durumda değerler eğitimi derslerinin, değerler eğitiminin gereğine olan inancı arttırmakta etkili olduğu söylenebilir.

Deney grubunun, değerler eğitiminin gereğine inanç faktöründen aldığı öntest ve sontest puanları arasında anlamlı bir farklılık olduğu görülmektedir, $t_{(43)}=-7.500, p=.000$. Deney grubuna dahil olan öğretmen adaylarının değer eğitiminin gereğine inanç faktöründen aldıkları puanlar uygulama öncesinde $\bar{X}=3.920$ iken, uygulama sonucunda $\bar{X}=4.420$ 'ye yükselmiştir. Bu bulgu, KDE dersinde yapılan video blog uygulamalarının, öğrencilerin değer eğitimine olan inançlarının artırmakta önemli bir etkiye sahip olduğunu göstermektedir.

\section{Değer eğitimini içselleştirme faktöründen elde edilen bulgular}

Bu bölümde kontrol ve deney grubunu oluşturan öğretmen adaylarının, DET ölçeğinin ikinci faktörü olan "Değer eğitimini içselleştirme" faktöründen almış oldukları öntest ve sontest puanları arasında anlamlı bir fark olup olmadığı incelenmiştir. Bu amaçla ilişkili örneklemler t-testi uygulanmıştır. Analizin sonuçlar1 Tablo 7'de sunulmuştur.

Tablo 7: Kontrol ve Deney Grubu Öğretmen Adaylarının, DET Ölçeği "Değer Eğitimini İçselleştirme" Faktöründen Almış Oldukları Öntest ve Sontest Puanlarının Bağımlı Örneklem T-Testi Sonuçları

\begin{tabular}{|c|c|c|c|c|c|c|c|c|c|}
\hline Faktör & Grup & Test & $\mathrm{N}$ & $\bar{X}$ & SS & $\mathbf{t}$ & sd & $\mathbf{p}$ & d \\
\hline \multirow{4}{*}{$\begin{array}{l}\text { Değerler eğitimini } \\
\text { içselleştirme }\end{array}$} & \multirow{2}{*}{ Kontrol } & Öntest & 44 & 3.344 & 0.553 & \multirow[t]{2}{*}{-2.820} & \multirow[t]{2}{*}{43} & \multirow[t]{2}{*}{.007} & \multirow[t]{2}{*}{.419} \\
\hline & & Sontest & 44 & 3.588 & 0.609 & & & & \\
\hline & \multirow{2}{*}{ Deney } & Öntest & 44 & 3.315 & 0.522 & \multirow{2}{*}{-7.084} & \multirow{2}{*}{43} & \multirow[b]{2}{*}{.000} & \multirow{2}{*}{1.265} \\
\hline & & Sontest & 44 & 3.968 & 0.510 & & & & \\
\hline
\end{tabular}

Tablo 7 incelendiğinde, kontrol grubunun değerler eğitimini içselleştirme faktöründen aldığı öntest ve sontest puanları arasında anlamlı bir farklılık olduğu görülmektedir, $t(43)=-2.820, p=.007, d=.419$. Kontrol grubuna dahil olan öğretmen adaylarının değerler eğitimini içselleştirme faktöründen aldıkları puanlar dersler öncesinde $\bar{X}=3.344$ iken, dersler sonucunda $\bar{X}=3.588$ 'e yükselmiştir. Etki büyüklüğü ise orta düzeydedir $(\mathrm{d}<.5)$. Bu durumda değerler eğitimi derslerinin, değerler eğitimini içselleştirilmesini arttırmakta etkili olduğu söylenebilir. 
Deney grubunun değerler eğitimini içselleştirme faktöründen aldığı öntest ve sontest puanları arasında da anlamlı bir farklılık olduğu görülmektedir, $t_{(43)}=-$ $7.084, p=.000$. Deney grubuna dahil olan öğretmen adaylarının değer eğitiminin gereğine inanç faktöründen aldıkları puanlar uygulama öncesinde $\bar{X}=3.315$ iken, uygulama sonucunda $\bar{X}=3.918$ 'e yükselmiştir. Etki büyüklüğünün oldukça büyük seviyede olduğu söylenebilir $(\mathrm{d}>=.8)$. Bu bulgu, KDE dersinde yapılan video blog uygulamalarının, öğretmen adaylarının değer eğitimi içselleştirmesini artırmakta önemli bir etkiye sahip olduğunu göstermektedir.

\section{Değer eğitimine yönelik olumsuz inanç faktöründen elde edilen bulgular}

$\mathrm{Bu}$ bölümde kontrol ve deney gruplarını oluşturan öğretmen adaylarının, DET ölçeğinin üçüncü faktörü olan "Değer eğitimine yönelik olumsuz inanç" faktöründen almış oldukları öntest ve sontest puanları arasında anlamlı bir fark olup olmadığı incelenmiştir. Bu faktörün altındaki ölçek maddelerinden elde edilen puanlar ters kodlama yapılmıştır. Dolayısı ile elde edilen daha yüksek puanlar daha az olumsuz inancı göstermektedir. Uygulanan ilişkili örneklemler t-testinin analizine ilişkin sonuçları Tablo 8'de sunulmuştur.

\begin{tabular}{|c|c|c|c|c|c|c|c|c|c|}
\hline & & & $\mathrm{N}$ & $\overline{\mathrm{X}}$ & SS & $\mathrm{t}$ & $\mathrm{sd}$ & $\mathrm{p}$ & d \\
\hline \multirow{4}{*}{$\begin{array}{l}\text { Değerler eğitimine } \\
\text { yönelik olumsuz } \\
\text { inanç }\end{array}$} & \multirow{2}{*}{ Kontrol } & Öntest & 44 & 4.237 & 0.420 & \multirow{2}{*}{0.259} & \multirow{2}{*}{43} & \multirow{2}{*}{.797} & \multirow{2}{*}{.037} \\
\hline & & Sontest & 44 & 4.221 & 0.425 & & & & \\
\hline & \multirow{2}{*}{ Deney } & Öntest & 44 & 4.062 & 0.453 & \multirow{2}{*}{-8.218} & \multirow{2}{*}{43} & \multirow{2}{*}{.000} & \multirow{2}{*}{1.624} \\
\hline & & Sontest & 44 & 4.647 & 0.233 & & & & \\
\hline
\end{tabular}

Tablo 8 incelendiğinde, kontrol grubunun değerler eğitimine yönelik olumsuz inanç faktöründen aldığı öntest ve sontest puanları arasında anlamlı bir farklılık olmadığ görülmektedir, $t(43)=0.259, p=.797, d=.037$. Kontrol grubuna dahil olan öğretmen adaylarının değer eğitimine yönelik olumsuz inanç faktöründen aldıkları puanlar dersler öncesinde $\bar{X}=4.327$ iken, dersler sonucunda $\bar{X}=4.221$ 'e düşmüştür. Etki büyüklüğü ise küçük düzeydedir $(\mathrm{d}<.2)$. Bu durumda değerler eğitimi derslerinin, değerler eğitimine yönelik olumsuz inanç üzerinde önemli bir etkiye sahip olmadığı söylenebilir.

Deney grubunun değerler eğitimine yönelik olumsuz inanç faktöründen aldığ1 öntest ve sontest puanları arasında ise anlamlı bir farklılık olduğu görülmektedir, $t(43)=-8.218, p=.000, d=1.604$. Deney grubuna dahil olan öğretmen adaylarının değer eğitimine yönelik olumsuz inanç faktöründen aldıkları puanlar uy- 
gulama öncesinde $\bar{X}=4.062$ iken, uygulama sonucunda $\bar{X}=4.647$ 'e yükselmiştir. Etki büyüklüğünün oldukça büyük seviyede olduğu söylenebilir $(\mathrm{d}>=.8) . \mathrm{Bu}$ bulgu, KDE dersinde yapılan video blog uygulamalarının, öğrencilerin değer eğitimine yönelik olumsuz inancı azaltmakta önemli bir etkiye sahip olduğunu göstermektedir.

\section{Öğretmen Adayları ile Yapılmış Yarı-Yapılandırılmış Görüşmeler- den Elde Edilen Bulgular}

Deney grubuna dahil olan 11 öğretmen adayı ile KDE dersinin bitiminde yarı yapılandırılmış görüşmeler gerçekleştirilmiştir. Bu görüşmelerden elde edilen bulgular bu bölümde sunulmuştur.

\section{Değerler eğitimine olan bakış açılarında meydana gelen değişiklik}

Yarı yapılandırılmış görüşmelere katılan deney grubu öğrencilerinin video blog etkinlikleri sonucunda değerler eğitimine olan bakış açılarında meydana gelen değişikliğe ilişkin bulgular Tablo 9'da sunulmuştur.

Tablo 9: Video Blog etkinlikleri Sonucunda Değerler Eğitimine Olan Bakış Açılarında Meydana Gelen Değişiklikler

\begin{tabular}{llll}
\hline & & Öğrenci Sayısı (N) & f (\%) \\
\hline \multirow{3}{*}{ Olumlu yönde değişim } & Daha önemli & 6 & $\% 54.5$ \\
\cline { 2 - 4 } & Daha yararlı & 5 & $\% 45.5$ \\
\cline { 2 - 4 } & Toplam & $\mathbf{1 1}$ & $\% 100$ \\
\hline
\end{tabular}

Tablo 9 incelendiğinde, görüşmelere katılan öğrencilerin tamamının (\% 100, $\mathrm{f}=11$ ) değerler eğitime olan bakış açılarında olumlu yönde bir değişim meydana geldiğini belirttiği görülmektedir. Öğretmen adayları dersin sonunda değerler eğitiminin daha önemli (\% 54.5, $\mathrm{f}=6)$ ve daha yararlı $(\% 45.5, \mathrm{f}=5)$ olduğunu düşünmektedir. Konu ile ilgili görüşlerden bazıları aşağıdaki gibidir;

Yazarken de eleştiri yapıyorsunuz ya, Kendinizi sorguluyorsunuz, O yüzden yararlı olduğunu düşünüyorum (A4).

Önceden pek bilmediğim bir konuydu. Fakat içine girdikçe daha da önemsenecek bir konu olduğunu düşünüyorum (A3).

\section{Video blog etkinliklerinin KDE dersine etkisi}

Yarı yapılandırılmış görüşmelere katılan deney grubu öğrencilerinin video blog etkinliklerinin KDE dersine olan etkisi hakkındaki görüşlerine ilişkin bulgular Tablo 10'da sunulmuştur. 


\begin{tabular}{llll}
\hline Tablo 10: Video Blog Etkinliklerinin KDE Dersine Katkısı & & \\
\hline & & $\begin{array}{l}\text { Öğrenci Sayısı } \\
\text { (N) }\end{array}$ & f (\%) \\
\hline & Daha akılda kalıcı & 7 & $\% 63,6$ \\
\cline { 2 - 4 } Olumlu yönde değişim & Daha ilgi çekici & 5 & $\% 45,5$ \\
\cline { 2 - 4 } & $\begin{array}{l}\text { Öğrencilerin derse katılımını kolay- } \\
\text { laştırıcı }\end{array}$ & 4 & $\% 36,4$ \\
\cline { 2 - 4 } & Toplam & $\mathbf{1 1}$ & $\mathbf{0 ~ 1 0 0}$ \\
\hline
\end{tabular}

Tablo 10 incelendiğinde, görüşmelere katılan öğrencilerin tamamının (\% 100, $\mathrm{f}=11$ ) video blog etkinliklerinin KDE dersine olumlu yönde etki ettiğini belirttiği görülmektedir. Öğretmen adayları etkinlikler sonunda dersin daha akılda kalıcı (\% 63,6, f=7), daha ilgi çekici (\% 45.5, f=5) ve öğrencilerin derse katılımını kolaylaştırıcı (\% 36,4, f=4) olduğunu düşünmektedir. Konu ile ilgili görüşlerden bazıları aşağıdaki gibidir;

Sınıf blogları görsel olduğu için unutmuyoruz daha iyi hatırda kalıyor (A9).

Bence bu şekilde herkesin ilgisini daha çok çekiyor (A1).

\section{Örnek olay videolarının yorumlanması yönteminin değerler eği- timinde kullanımı}

Yarı yapılandırılmış görüşmelere katılan deney grubu öğrencilerinin örnek olay videolarının yorumlanması yönteminin değerler eğitiminde kullanımı hakkındaki görüşlerine ilişkin bulgular Tablo 11'de sunulmuştur.

\begin{tabular}{lll}
\hline \multicolumn{2}{l}{ Tablo 11: Örnek Olay Videolarının Yorumlanması Yönteminin Değerler Eğitiminde Kullanımı } \\
\hline & Öğrenci Sayısı (N) & f (\%) \\
\hline Değerlerin kazandırılmasında etkili & 6 & $\% 54,5$ \\
\hline Öğrencileri daha iyi tanıma imkânı sunar & 2 & $\% 18,2$ \\
\hline Öğrencilerin birbiri ile etkileşimde bulunmasını sağlar & 1 & $\% 9,1$ \\
\hline
\end{tabular}

Tablo 11 incelendiğinde, öğretmen adaylarının örnek olay videolarının video blog üzerinde yorumlanması yönteminin değerler eğitiminde kullanımının, değerlerin kazandırılmasında etkili olduğu (\% 54.4, f=6) ve öğrencileri daha iyi tanıma imkanı sunduğu (\% 18.2, f=2) yönünde görüş belirtmişlerdir. Konu ile ilgili görüşlerden bazıları aşağıdaki gibidir;

Bence videoları tartışan ögrencilerin değerleri özümseme miktarı artar. Çünkü Demek ki ilgisini çekmiş ki eleştirmek için de bir fikri var (A5).

Bir video verirdim ve bununla ilgili görüşlerini yazmaların isterdim. Ki ben onları tanıya bileyim, nerede eksikleri olduğunu görebileyim (A7). 


\section{Öğretmen adaylarının video blog uygulaması ile ilgili tavsiyeleri}

Yarı yapılandırılmış görüşmelere katılan deney grubu öğrencilerinin KDE derslerinde video blog uygulamasına ilişkin tavsiyelerine ilişkin bulgular Tablo 12 'de sunulmuştur.

Tablo 12: Video Blog Uygulaması İle İlgili Tavsiyeler

\begin{tabular}{lll}
\hline & Öğrenci Sayısı (N) & $\mathbf{f}(\mathbf{0})$ \\
\hline Daha fazla paylaşım & 5 & $\%$ 45,5 \\
\hline Videolar derste yorumlanmalı & 4 & $\% 36,4$ \\
\hline Uygulama yaygınlaştırılmalı & 2 & $\% 18,2$ \\
\hline Blogda etkileşimi arttırmak için ödül sistemi & 1 & $\% 9,1$ \\
\hline Videolar blogda yorumlanmalı & 1 & $\% 9,1$ \\
\hline Daha profesyonel videolar kullanılmalı & 1 & $\% 9,1$ \\
\hline
\end{tabular}

Tablo 12 incelendiğinde, öğretmen adaylarının video blog uygulamasının KDE derslerinde kullanımında daha fazla paylaşım yapılması ( $\% 45.5, \mathrm{f}=5)$, videoların derste yorumlanması $(\% 36.4, \mathrm{f}=24)$ ve uygulamanın yaygınlaştırılması (\% 18.2, f=2) gibi tavsiyelerde bulunduğu görülmektedir. Konu ile ilgili görüşlerden bazıları aşağıdaki gibidir;

Öğrenciler tarafindan hazırlanan videoların yanında birkaç tane de profesyonel video eklenebilir (A10).

Yorumların sınıf ortamında yapılmasının daha samimi bir ortam oluşturacağ kanaatindeyim (A11).

\section{Sonuç, Tartışma ve Öneriler}

KDE dersinde gerçekleştirilen video blog uygulamalarının öğretmen adaylarının değer eğitimine yönelik tutumları üzerindeki etkisini ve öğretmen adaylarının bu uygulamalar hakkındaki görüşlerini incelenmesinin amaçlandığ bu araştırmanın tartışma ve önerilerine bu bölümde yer verilmiştir.

KDE dersinde gerçekleştirilen video blog uygulamalarına katılan öğretmen adaylarının değer eğitimine yönelik tutumları ile dersi geleneksel yöntemlerle işleyen öğrenmen adaylarının tutumları arasında anlamlı bir fark olduğu, video blog etkinliklerine katılan öğretmen adaylarının tutum puanlarının daha yüksek olduğu görülmüştür. İki grubun yüz yüze derslerde aynı uygulamaları gerçekleştirmiş olduğu düşünülürse, video blog etkinliklerinin bu farkın kaynağı olduğu söylenebilir. Öğretmen adaylarının değerler eğitimine yönelik bu olumlu tutum değişiminde, video blog kullanımı etkinliklerinin değerler eğitiminde etkili 
olması, BİT ve videoları işe koşması nedeni ile daha eğlenceli olması, değerler eğitimini kısıtlı ders saatlerinin dışına taşıması nedeni ile daha uygulanabilir olması gösterilebilir. Öğretmenlerin değerler eğitimine yönelik tutumlarının olumlu yönde olması değerler eğitiminin başarılı olması için önemlidir. Çünkü olumlu tutum sahibi öğretmenler değerler eğitimine yönelik etkinlikler gerçekleştirmek için daha fazla motive olacaklardır. Ayrıca öğretmenlerin çocuklar için özellikle değerler ile ilgili konularda rol model olması nedeni ile öğretmen adaylarının değerler eğitiminin önemini kabullenmiş olması önemlidir.

Öğretmen adaylarının değerler eğitimine yönelik olan bu tutum değişimi üzerinde daha derinlemesine analiz yapabilmek için yarı yapılandırılmış görüşmelerden faydalanılmıştır. Öğretmen adaylarının tamamı video blog etkinliklerinin sonucunda değerler eğitimine olan bakış açılarında olumlu yönde değişim olduğunu, değerler eğitiminin "daha önemli” ve "daha yararlı" olduğunu düşündüklerini belirtmişlerdir. Bu sonuç video blog etkinliklerinin öğretmen adaylarının değerler eğitimine olan tutumlarını olumlu yönde etkilediğine ilişkin ve araştırmanın nicel sonuçlarını destekler nitelikte bir başka veri olarak sunulabilir.

Öğretmenlerin ve öğretmen adaylarının değerler eğitimine yönelik tutumları ile ilgili birçok çalışma farklı branşlardan öğretmenler ile gerçekleştirilmiştir (Kozikoğlu, 2018; Öztürk \& Dilmaç, 2016; Çetin, 2015; Yaşaroğlu, 2014; Çelikkaya \& Filoğlu, 2014; Durmuş vd., 2008). Okul öncesi öğretmenleri ile yapılan bir çalışmada, öğretmenlerin değerler eğitimine yönelik yüksek düzeyde olumlu tutum sergiledikleri ancak öğretmenlerin değerler eğitimine yönelik somut etkinliklerin yetersiz olduğu görüşünde oldukları belirlenmiştir (Kozikoğlu, 2018). Aynı şekilde sınıf öğretmenleri (Yaşaroğlu, 2014) ile yapılan çalışmada değerler eğitimine yönelik tutumun olumlu yönde olduğu belirlenmiştir. Öztürk ve Dilmaç (2016), görsel sanat öğretmenlerinin değerler eğitimine yönelik tutumlarının mezuniyet düzeyine göre farklılaştığı ancak mezuniyet türüne göre farklılaşmadığını sonucuna ulaşmıştır. Yaşaroğlu (2014) mezun olunan okul türüne göre değerler eğitimine yönelik tutumda farklılaşma, Durmuş vd. (2008) değerler eğitimi tutum puanında eğitim fakülteleri yönünde anlamlı düzeyde farklılaşma tespit etmiştir. Bu sonuçlar eğitim fakültelerinde alınan eğitimin, öğretmenlerin değerler eğitimine yönelik tutumları üzerinde önemli bir etmen olduğunu ortaya koymaktadır. Dolayısı ile mevcut araştırmanın sonuçları daha önce yapılmış araştırmaları değerler eğitimine yönelik tutum yönünden desteklemektedir.

Araştırma sonucunda elde edilen bir başka bulgu da, deney grubunun ve kontrol grubunun DET ölçeğinin "değerler eğitiminin gereğine inanç" faktöründen 
aldığ 1 öntest ve sontest puanları arasında anlamlı bir farklılık olduğu, KDE dersi ve video blog etkinlikleri sonucunda öğretmen adaylarının değerler eğitiminin gereğine olan inancının arttığı olmuştur. Ancak sontest ortalamaları ve etki büyüklüğü değerleri incelendiğinde, deney grubunda artışın çok daha yüksek düzeyde olduğu görülmektedir. Deney grubu ile gerçekleştirilen ders ve video blog etkinliklerinde, öğretmen adaylarının değerler eğitimi hakkındaki farkındalığının artması için yapılan çalışmalar nedeni ile bu beklenilen bir sonuç olmuştur. Şahin (2019), bu çalışmada da kullanılmış olan DET ölçeği kullanarak yapmış olduğu çalışmada KDE dersini alan öğretmen adaylarının tutumlarını incelemiştir. Çalışmada DET ölçeğinin "Değer Eğitiminin Gereğine İnanç" alt faktöründen alınan öntest ve sontest puanları arasında anlamlı bir farklılık görülmüştür. Dolayısı ile iki çalışmada elde edilen sonuçlar aynı yöndedir. Benzer sonuçlar öğretmen adaylarının değerler eğitimine yönelik görüşlerinin alınd1ğ1 çalışmalarda da görülmüş, öğretmen adayları değerler eğitiminin önemini ve gerekliliğini ifade etmişlerdir (Katılmış \& Balc1, 2017; Oğuz, 2012, Fidan, 2009). Öğretmenlerin değerler eğitiminde rol model olma görevini üstlenmeleri gereği nedeni ile değerler eğitiminin gereğine inancı tam olan öğretmenlerin, ileride meslek yaşamlarında değerler eğitimi uygulamalarında daha başarılı olmaları beklenmektedir. Bu durum öğretmen adaylarına değerler eğitiminde kullanılabilecek teknik ve yöntemler hakkında eğitim verilmesinin gerekliliğini ortaya koymaktadır.

Deney ve kontrol gruplarının DET ölçeğinin ikinci faktörü olan "değerler eğitimini içselleştirme" faktöründen aldıkları öntest ve sontest puanları arasında da anlamlı bir fark bulunmuş, ögretmen adaylarının KDE dersi ve video blog etkinlikleri sonrasında değerler eğitimini daha fazla içselleştirdiği tespit edilmiştir. Ancak grupların sontest ortalamaları ve etki büyüklüğü değerleri incelendiğinde, deney grubunda uygulamalar sonunda gerçekleşen artışın daha büyük ölçekte olduğu görülmektedir. Şahin (2019) tarafindan gerçekleştirilen ve DET ölçeğinin uygulandığı bir çalışmada, DET ölçeğinin "değer eğitimini içselleştirme" faktöründen elde edilen puanların KDE dersi sonucunda arttığı, dersten önce uygulanan öntest ve dersten sonra uygulanan sontest puanlarının anlamlı bir farklılık gösterdiği görülmüştür. İki çalışmanın sonuçları bu açıdan birbirini destekler niteliktedir. Öğrencilerin değerleri içselleştirme düzeyleri üzerinde yapılan çalışmada, değerler eğitimi sonucunda öğrencileri farklı değerleri içselleştirme düzeylerinde artış olduğu gözlemlenmiştir (Aladağ, 2012). Öğretmen adaylarının görüşleri alınarak yapılan bir çalışmada ise, öğretmen adaylarının öğretmenlik mesleğini yürütürken değer eğitiminde öğrencilerine rol model ol- 
maları gerektiğinin farkına vardıkları anlaşılmıştır (Bayır vd., 2016). Öğretmen adaylarının değerler eğitiminde rol model olma görevini yürütebilmeleri ancak değerler eğitimini içselleştirmeleri ile mümkün olabilecektir. Bu açıdan verilen eğitimlerin başarılı olduğu söylenebilir.

DET ölçeğinin üçüncü faktörü olan "değer eğitimine yönelik olmuşuz inanç" faktöründen deney grubunun öntest ve sontest puanları arasında da anlamlı bir fark bulunmuş, öğretmen adaylarının KDE dersi ve video blog etkinlikleri sonrasında değerler eğitimine yönelik olumsuz inançlarının neredeyse kaybolduğu belirlenmiştir. Kontrol grubunda ise anlamlı bir fark gözlemlenmemiş, standart ders içeriğinin öğretmen adaylarının değerler eğitimine yönelik olumsuz inancını azaltmakta etkili olmadığı gözlemlenmiştir. Şahin (2019) tarafından yapılan çalışmada ise, KDE dersine katılan öğrencilerin DET ölçeğinin "değer eğitimine yönelik olumsuz inanç” faktöründen aldıkları öntest ve sontest puanları arasında anlamlı bir fark gözlemlenmemiştir. Bu açıdan iki çalışmanın sonuçları örtüşmemektedir. Ancak öğretmen adaylarının genel olarak değerler eğitimine olan tutumlarında gözlemlenen olumlu değişme göz önüne alındığında, öğretmen adaylarının olumsuz inançlarında azalma meydana gelmesi beklenen bir durumdur. Çalışmanın öntest puanı incelendiğinde, öğretmen adaylarının etkinliklerin öncesinde değerler eğitimine yönelik olumsuz inançlarının oldukça düşük düzeyde olduğu gözlemlenmiştir. Yapılan etkinlikler sonucunda öğretmen adaylarının değerler eğitiminin gereksizliği, harcanan zamanın boşa geçmiş olduğu, sıkıcı olduğu, abartıldığı gibi olumsuz inançların neredeyse tamamen yok olduğu görülmektedir.

Öğretmen adayları ile yapılan yarı yapılandırılmış görüşmelerde ise doğrudan video blog etkinlikleri hakkında veri toplanılması amaçlanmıştır. Öncelikle öğretmen adaylarının tamamı video blog etkinliklerinin KDE dersine olumlu yönde etki yaptı̆̆ını yönünde görüş bildirmiş, dersi daha akılda kalıcı, daha ilgi çekici ve öğrencilerin derse katılımını kolaylaştırıcı hale getirdiğini belirtmişlerdir. Bu sonuçlardan hareketle video blog etkinliklerinin, öğretmen adaylarına verilecek KDE derslerinde etkinlik olarak gerçekleştirilmesi ve yöntemin öğretmen adaylarına tanıtımının yapılması önerilmektedir. Böylece, öğretmen adayları ileride meslek yaşamlarında değerler eğitimine yönelik yapacakları çalı̧̧malarda kendilerini daha hazır hissedecekler, değerler eğitimine yönelik çalışmalar yürütme konusunda daha istekli olacaklardır.

Video blog etkinliklerinde öğretmen adaylarının örnek olay videoları için yaptıkları analizleri, paylaşımların altına bulunan yorum bölümlerine yazmaları 
istenmiştir. Bu uygulama için öğretmen adayları "değerlerin kazandırılmasında etkili”, "öğrencileri daha iyi tanıma imkânı sunar" ve "öğrencilerin birbiri ile etkileşimde bulunmasını sağlar" şeklinde yorumlarda bulunmuşlardır. Değerler eğitimini etkili bir şekilde yürütmek için kullanılan yaklaşımlardan birisi de “değer analizi” yaklaşımıdır. Değer analizi yaklaşımında öğrencinin incelenen örnek olayı sadece izleyerek geçmemesi, olay üzerinde düşünerek neden ve nasıl sorularını yöneltmesi, olayın günlük yaşamdaki benzer durumlarla olan farklılıklarını ve benzerliklerini değerlendirmesi beklenir. Bu açıdan video blog etkinliklerinde öğrencilerden örnek olay videolarını analiz etmesinin istenmesi, değer analizi yaklaşımına uygun bir uygulamadır. Öğretmen adayları da görüşlerinde bu uygulamanın değerler eğitimi sürecine katkı sunduğunu, sınıf içi etkileşimi artırdığını belirterek, örnek olay videolarının yorumlanması uygulamasını desteklemişlerdir.

Öğretmen adaylarının ayrıca video blog etkinliklerinin gelecekte yapılacak uygulamaları için önerileri de alınmıştır. Öğretmen adayları daha fazla paylaşım ve daha profesyonel videolar görmek istediklerini belirtmiş̧lerdir. Çalışma kapsamında yapılan örnek olay video paylaşımları, önceki dönemlerde KDE dersine katılmış olan öğretmen adaylarınca hazırlanmış olan videoların içerisinde seçilerek yapılmıştır. Daha fazla paylaşım yapılabilmesi için değerler eğitimine yönelik daha fazla örnek olay videosu hazırlanmalıdır. Hatta bu konunda profesyonel ekiplerden yardım alınarak videoların kalitesi arttırılabilir. Az sayıda öğrenci videoların yorumlanmasının derste yüzyüze yapılmasını savunmuştur. Ancak bu uygulama video blogların sunduğu en önemli avantaj olan değerler eğitimi etkinliklerini sınıf dışına taşımayı engelleyeceği için uygun bulunmamıştır. Bunu dışında öğretmen adayları uygulamanın yaygınlaştırılması ve etkileşimi arttırmak için ödül sisteminin kullanılması gibi önerilerde de bulunmuşlardır. Ödül sisteminin kullanılmasının, yapılan yorumların doğruluğuna azaltabileceği gerekçesi ile uygun bulunmamıştır ancak uygulamaların yaygınlaştırılması araştırmanın önerileri arasında yer almaktadır.

Araştırmanın sonuçlarından hareketle alanda yapılacak yeni çalışmalara yönelik birçok öneri sunulabilir. Örneğin, video çekimi konusunda profesyonel ekiplerce ve profesyonel oyuncularca, değerler eğitimi konusunda uzman akademisyenlerin katkısı ile değerler eğitimine yönelik daha fazla örnek olay videosu üretilebilir. Yurtdışında bu konuda çok sayıda içerik olmasına rağmen Türkçe içerik çok sınırlıdır. Çalışan öğretmenlere yönelik düzenlenecek hizmet içi eğitimler ile değerler eğitimine yönelik video blog etkinliklerinin tanıtımı 
yapılabilir, yöntemin uygulamasına yönelik öğretmenlere eğitim verilebilir. Video blog etkinlikleri örgün eğitim öğrencileri ve eğitim verilen öğretmenler ile birlikte gerçekleştirilebilir ve değerler eğitimine ilişkin yaptığı katkılar hakkında veri toplanabilir. Okullarda gerçekleştirilecek video blog uygulamaları sonucunda yöntemin uygulanmasında yaşanılan güçlükler gözlemlenebilir ve yöntem bu sonuçlar doğrultusunda geliştirilebilir. Son olarak, öğretmen adaylarına yönelik olarak video blog etkinlikleri dahil olmak üzere etkililiği kanıtlanmış yöntemlerin kullanımına ilişkin eğitimler verilebilir. KDE dersin içeriği daha fazla uygulamalı yönelik hale getirilmelidir.

\section{Kaynakça}

Aktepe, V., \& Tahiroğlu, M. (2016). Değerler eğitimi yaklaşımları ve etkinlik örnekleri. The Journal of Academic Social Science Studies, 42, 361-384. http://dx.doi.org/10.9761/JASSS2941

Aladağ, S. (2012). İlköğretim sosyal bilgiler öğretiminde değer eğitimi yaklaşımlarının öğrencilerin sorumluluk değerini bilişsel düzeyde kazanmalarına etkisi. Türkiye Sosyal Araştırmalar Dergisi, 16(1), 123-146.

Atıcı, B., \& Özmen, B. (2011, Mayıs). Blog kullanımının sınıf topluluğu duygusuna etkisi. Uluslararası Eğitim Teknolojileri Sempozyumu, İstanbul.

Aydın, M. Z. (2017, Kasım). Eğitim sistemimizde değerler eğitiminin önemi. Yenidünya Dergisi. http://yenidunyadergisi.com/egitim-sistemimizde-degerler-egitiminin-onemi/

Akbaş, O. (2008). Değer eğitimi akımlarına genel bir bakış. Değerler Eğitimi Dergisi, 6(16), 9-27.

Baltacı, M., \& Akpınar, B. (2011). Web tabanlı öğretimin öğrencilerin akademik başarısına etkisi. Fırat Üniversitesi Sosyal Bilimler Dergisi, 21(1), 77-88.

Bayır, G. Ö., Köse, Ç. T., \& Birlik, E. (2016). Sınıf öğretmeni adaylarına göre ilkokullarda değer eğitimi. Ahi Evran Üniversitesi Kırşehir Eğitim Fakültesi Dergisi, 17(3), 317-339.

Büyüköztürk, Ş. (1998). Kovaryans analizi: Varyans analizi ile karşılaştırmalı bir inceleme. Eğitim Bilimleri Fakültesi Dergisi, 31(1), 91-105.

Büyüköztürk, Ş. (2008). Sosyal bilimler için veri analizi el kitabı (9. Baskı). Pegem Akademi.

Büyüköztürk, Ş. (2016). Deneysel desenler: Öntest-sontest kontrol grubu, desen ve veri analizi. Pegem Akademi.

Ching, G. S. (2012). Blog assisted learning: Experiences in learning business English vocabularies. International Journal of Research Studies in Educational 
Technology, 1(1), 3-12. https://www.learntechlib.org/p/49781/

Cohen, J. (1988). Statistical power analysis fort the behavioral sciences (2nd ed.). Erlbaum.

Colombo, M. W., \& Colombo, P. D. (2007). Using blogs to improve differentiated instruction. Education Digest, 73(4), 10-14. https://www.dentonisd.org/cms/ lib/tx21000245/centricity/Domain/900/diffedblog.pdf

Çelikkaya, T., \& Filoglu, S. (2014). Attitudes of social studies teachers toward value and values education. Educational Sciences: Theory and Practice, 14(4), 1551-1556. https://files.eric.ed.gov/fulltext/EJ1045069.pdf

Çetin, F. (2018). Değer eğitimine yönelik tutum ölçeği (DETÖ) geçerlik ve güvenirlik çalışması. Türkiye Sosyal Araştırmalar Dergisi, 22(1), 323-341.

Çetin, Ş. (2015). Milli değerlerin öğretimine yönelik tutum ölçeği (MDÖTÖ) geçerlik ve güvenirlik çalışması. Electronic Turkish Studies, 10(11), 447-460.

Divitini, M., Haugalokken, O., \& Morken, E. M. (2005). Blog to support learning in the field: Lessons learned from a fiasco. Fifth IEEE International Conference on Advanced Learning Technologies (ICALT'05), 219-221.

Dunlap, J. W. (2005). “VeggieTales”: Moral education through entertainment-education videos (Unpublished $\mathrm{PhD}$ Thesis). Regent University, US.

Durmuş, S., Bıçak, B. \& Çakır, S. (2008). Fen ve teknoloji, matematik ve sınıf ögretmenlerinin sahip oldukları matematik ve matematik eğitimi değerlerinin farklı değişkenler açısından incelenmesi. Değerler Eğitimi Dergisi, 6(16), 93-112.

Erdemir, Ö. G. M., \& İngeç, Ş. K. (2014). Fizik eğitiminde web tabanlı zeki öğretim sisteminin (ZÖS) başarıya etkisi. Ĕgitim ve Öğretim Araştırmaları Dergisi, 3(1), 289-298.

Ersoy, F. \& Ünüvar, F. (Eds.). (2019). Karakter ve değerler eğitimi. Anı Yayıncılık.

Fidan, N. K. (2009). Öğretmen adaylarının değer öğretimine ilişkin görüşleri. $K u$ ramsal Eğitimbilim Dergisi, 2(20), 1-18. https://keg.aku.edu.tr/arsiv/c2s2/ KuramsalEgitimbilim_cilt2say\%c3\%84\%c2\%b12.pdf

Fidan, N. K. (2017). Views of the classroom teachers about the contributions of certain days and weeks to value education. Pegem Egitim ve Ögretim Dergisi, 7(2), 287-312. https://doi.org/10.14527/pegegog.2017.011

Fidan, M., \& Debbağ, M. (2018). The usage of video blog (vlog) in the" school experience" course: The opinions of the pre-service teachers. Journal of Education and Future, (13), 161-177.

Field, A. \& Miles, J. (2010). Discovering statistics using SAS. Sage. 
Gao, W., Tian, Y., Huang, T., \& Yang, Q. (2010). Vlogging: A survey of videoblogging technology on the web. ACM Computing Surveys (CSUR), 42(4), 1-57. https://doi.org/10.1145/1749603.1749606

George, D., \& Mallery, M. (2010). SPSS for windows step by step: A simple guide and reference (10. ed.). Pearson.

Göktaş, Y., \& Demirel, T. (2012). Blog-enhanced ICT courses: Examining their effects on prospective teachers' ICT competencies and perceptions. Computers \& Education, 58(3), 908-917. https://doi.org/10.1016/j.compedu.2011.11.004

Güçlü, M. (2015). Türkiye'de değerler eğitimi konusunda yapılan araştırmalar. Uluslararası Sosyal Araştırmalar Dergisi, 8(38). 720-732. http://www. sosyalarastirmalar.com/cilt8/sayi38pdf/5egitim/guclu_mustafa.pdf

Halic, O., Lee, D., Paulus, T., \& Spence, M. (2010). To blog or not to blog: Student perceptions of blog effectiveness for learning in a college-level course. The Internet and Higher Education, 13(4), 206-213. https://doi.org/10.1016/j. iheduc.2010.04.001

Hramiak, A., Boulton, H., \& Irwin, B. (2009). Trainee teachers' use of blogs as private reflections for professional development. Learning, Media and Technology, 34(3), 259-269. https://doi.org/10.1080/17439880903141521

Hung, S. T. (2011). Pedagogical applications of vlogs: An investigation into ESP learners' perceptions. British Journal of Educational Technology, 42(5), 736-746. https://doi.org/10.1111/j.1467-8535.2010.01086.x

Husin, M. R. B., Ahmad, H. B., \& Hamzah, M. B. (2019). Video application to accommodate students' learning style for moral education in teacher education institutes. Indonesian Journal of Electrical Engineering and Computer Science, 16(1), 349-354.

İşcan, C. D. (2007). Illköğretim düzeyinde değerler eğitimi programının etkililiği (Yayınlanmamış Doktora Tezi). Hacettepe Üniversitesi Sosyal Bilimler Enstitüsü, Ankara.

Kajder, S. \& Parkes, K. (2012). Examining preservice teachers' reflective practice within and across multimodal writing environments. Journal of Technology and Teacher Education, 20(3), 229-249. https://www.learntechlib.org/primary/p/37489/.

Karger, D. R., \& Quan, D. (2005). What would it mean to blog on the semantic web?. Journal of Web semantics, 3(2-3), 147-157.

Katılmış, A., \& Balcı, A. (2017). Coğrafya öğretmeni adaylarının değerler eğitimine yönelik görüşlerinin incelenmesi. Marmara Coğrafya Dergisi, 35, 1-12. 
Kıral, E. \& Kıral, B. (2011). Karma araştırma yöntemi (mixed research design). $2^{\text {nd }}$ International Conference on New Trends in Education and Their Implications. http://www.iconte.org/FileUpload/ks59689/File/050.pdf

Kozikoğlu, İ. (2018). Okul öncesi öğretmenlerinin değerler eğitimine ilişkin tutum ve görüşlerinin incelenmesi. Uluslararası Türkçe Edebiyat Kültür Eğitim (TEKE) Dergisi, 7(4), 2698-2720. https://dergipark.org.tr/en/download/article-file/623595

Kuşdil, M. E., \& Kağıtçıbaşı, Ç. (2000). Türk öğretmenlerin değer yönelimleri ve Schwartz değer kurami. Türk Psikoloji Dergisi, 15(45), 59-80.

Liu, M. H. (2016). Blending a class video blog to optimize student learning outcomes in higher education. The Internet and Higher Education, 30, 44-53. https://doi.org/10.1016/j.iheduc.2016.03.001

Lokman, H. F., Yusoff, N. M. R. N., Khalid, F., \& Nasri, N. M. (2018). The feedback of using edmodo application in teaching and learning of moral education in secondary school. International Journal of Academic Research in Progressive Education and Development, 7(4), 246-254. http://dx.doi.org/10.6007/ IJARPED/v7-i4/4851

Mansor, A. Z. (2011). Reflective learning journal using blog. Procedia-Social and Behavioral Sciences, 18, 507-516. https://doi.org/10.1016/j.sbspro.2011.05.074

Memiş, A., \& Gedik, E. G. (2010). Sınıf öğretmenlerinin değer yönelimleri. Değerler Eğitimi Dergisi, 8(20), 123-142.

Miles, J., \& Banyard, P. (2007). Understanding and using statistics in psychology: A practical introduction. Sage.

Miles, M. B., \& Huberman, A. M. (1994). Qualitative data analysis. Sage.

Millî Eğitim Bakanlığı. (n.d.). Değerler eğitimi yönergesi. http://mebk12.meb.gov. tr/meb_iys_dosyalar/34/39/749197/dosyalar/2015_02/09093609_degerleregitimi.pdf

Narinasamy, I., \& Mamat, W. H. W. (2013). Utilization of ICT by moral education teachers. The Malaysian Online Journal of Educational Technology, 1(4), 44-53. http://www.mojet.net/frontend/volume/mojet-volume01-issue04.pd$\mathrm{f}$ \#page $=50$

Oğuz, E. (2012). Öğretmen adaylarının değerler ve değerler eğitimine ilişkin görüşleri. Kuram ve Uygulamada Eğitim Bilimleri, 12(2), 1309-1325.

Öztürk, D., \& Dilmaç, O. (2016). Görsel sanatlar öğretmenlerinin değerler eğitimine ilişkin tutumlarının bazı değişkenler açısından incelenmesi. Journal of Bayburt Education Faculty, 11(1), 224-237. 
Parkes, K. A., Dredger, K. S., \& Hicks, D. (2013). Eportfolio as a measure of reflective practice. International Journal of ePortfolio, 3(2), 99-115. https://files. eric.ed.gov/fulltext/EJ1107797.pdf

Rodriguez-Conde, M. J., Olmos Miguelanez, S., Perochena Gonzalez, P., \& Herrera García, E. (2011). Moral education and improvement of coexistence in secondary education (12-16 Years) in Spain. Online Submission, 8(1), 98-102. https://files.eric.ed.gov/fulltext/ED519400.pdf

Ryan, K. (1991). Moral and values education. Arieh Lewy (Ed.). The international encyelopedia of curriculum, advences in education (pp. 736-742). Pergaman Press.

Shih, R. C. (2010). Blended learning using video-based blogs: Public speaking for English as a second language students. Australasian Journal of Educational Technology, 26(6), 883-897.

Sünbül, A. M. (2012). Eğitim gelişim ve değişim 1. Eğitim Yayınevi.

Özdaş, F. (2013). Ortaokullarda değerler eğitimi ve istenmeyen öğrenci davranışlartna ilişkin ögrretmen görüşlerinin değerlendirilmesi (Yayımlanmamış Doktora Tezi). Fırat Üniversitesi Eğitim Bilimleri Enstitüsü, Elazı̆̆.

Saban, A. (2000). Öğrenme öğretme süreci yeni teori ve yaklaşımlar. Nobel Yayınları.

Şahin, N. (2019). Türk dili ve edebiyatı öğretmeni adaylarının karakter ve değerler eğitimi dersine yönelik görüşlerinin incelenmesi. Uluslararası Toplum Araştırmaları Dergisi, 11(18), 1058-1090. https://doi.org/10.26466/ opus.569630

Schwartz, S. H. (1994). Are there universal aspects in the structure and contents of human values?. Journal of social issues, 50(4), 19-45.

Tang, E., \& Lam, C. (2014). Building an effective online learning community (OLC) in blogbased teaching portfolios. The Internet and Higher Education, 20, 79-85. https://doi.org/10.1016/j.iheduc.2012.12.002

Turan, R., \& Ulusoy, K. (Eds.). (2015). Farkl yönleriyle değerler ĕgitimi. Pegem Akademi.

Waely, S. A., \& Aburezeq, I. M. (2013). Using blogs to facilitate interactive and effective learning: Perceptions of pre-service arabic teachers. Journal of Language Teaching \& Research, 4(5), 975-985. https://pdfs.semanticscholar.org/8a9c/a1f91bc74d9d3e6d219db8797c2b2c897f49.pdf

Yaşaroğlu, C. (2014). Sınıf öğretmenlerinin değerler eğitimine yönelik tutumlarının çeşitli değişkenler açısından incelenmesi. The Journal of Academic Social Science Studies, 27, 503-515. 
Yang, J. C., Quadir, B., Chen, N. S., \& Miao, Q. (2016). Effects of online presence on learning performance in a blog-based online course. The Internet and Higher Education, 30, 11-20. https://doi.org/10.1016/j.iheduc.2016.04.002

Yıldırım, A., \& Şimşek, H. (2006). Sosyal bilimlerde nitel araştırma yöntemleri. Seçkin Yayıncılık.

Yıldırım, K. (2009). Values education experiences of Turkish class teachers: A phenomonological approach. Egitim Arastirmalari-Eurasian Journal of Educational Research, 35, 165-184.

Yu, H. (2011). A study on the development of web-based moral education course. International Conference on Uncertainty Reasoning and Knowledge Engineering, 2, 99-102.

Yükseltürk, E., \& Top, E. (2016). Web 2.0 teknolojilerinin öğretmen eğitiminde kullanımı, In K. Çağıltay \& Y. Göktaş (Eds.), Öğretim teknolojilerinin temelleri: teoriler, araştırmalar, eğitimler (pp. 555-570). Pegem Akademi. 
Extended Abstract

\section{Usage of Video Blog in Values Education}

Ozan COŞKUNSERÇE, Corresponding Author, Assistant. Professor

Nevşehir Hacı Bektaş Veli University, Education Faculty, Nevsehir/Turkey.

coskunserce@nevsehir.edu.tr

https://orcid.org/0000-0002-1230-324X

Article Type: Research Article

https://doi.org/10.34234/ded.767347

Received Date: 09.07 .2020

Accepted Date: 29.10 .2020

Published Date: 25.12 .2020

\section{Introduction}

Values education is among the basic objectives of education, in addition to its capacity in increasing students' academic knowledge levels and providing new skills to students. Values are also among the most important factors that enable a society to live together and connect its members. Values are stated to be difficult for students to internalize because education is a structure consisting of abstract concepts (Turan \& Ulusoy, 2015). Activities in the field of values education are expected to embody abstract concepts and make it easier for students to internalize these concepts. For this reason, it is important for teachers to have different applications to facilitate the internalization of values education inside and outside the classroom (Memiş \& Gedik, 2010).

Failure to perform out-of-class activities in values education is among the main problems in values education (Güçlü, 2015). It is possible to carry out values education out of the classroom by using Web technologies and thus ac- 
tivities for values education can be carried outside the limited course hours. Video blogs can be used to easily share case study videos that can be used in values education. Video blogs are a convenient tool for the use of a value analysis approach in values education, as it offers users the opportunity to express and discuss opinions and share them. It is possible to use case study videos and Web technologies together with video blogs, which offer many advantages, possibilities and solutions to the problems encountered in value education. With the introduction of this activity for values education, it is expected that there will be a positive change in the attitudes and perspectives of prospective teachers towards values education.

In this study, it was aimed to determine the effects of video blog activities performed in Character and Values Education (CVE) lesson on the attitudes of prospective teachers towards values education and their opinions regarding these activities.

For this purpose, the following questions were sought:

- Is there a significant difference between attitude scores of the experimental group in which the video blog activities are performed in the CVE course and the control group in which video blog activities is not carried out, towards values education?

- Is there a significant difference between the pre-test and post-test scores that prospective teachers who have made video blog activities in the CVE course in terms of belief in the values education?

- Is there a significant difference between the pre-test and post-test scores that prospective teachers who have made video blog activities in the CVE course in terms of internalizing values education?

- Is there a significant difference between the pre-test and post-test scores that prospective teachers who have made video blog activities in the CVE course have in terms of negative belief in values education?

- What are the opinions of prospective teachers about the video blog activities performed in the CVE course?

\section{Method}

Mixed research method was used in the study. In the quantitative dimension of the study, experimental design with pretest-posttest control group was used. In 
order to collect quantitative data in the study, Attitude towards Value Education (AVE) Scale was applied to the control and experimental groups at the beginning and end of the lessons as pretest and posttest. The qualitative dimension of the study consists of semi-structured interviews with 11 prospective teachers participating in video blog activities. The study group of the research consists of prospective teachers taking CVE course. While the CVE course of 44 prospective teachers who constitute the control group is taught within the regular course hour, video blog activities were held in the CVE course of the experimental group consisting of 44 prospective teachers. 25 of the prospective teachers in the experimental group are girls and 19 are boys. In the control group, there are 23 girls and 21 boys. Six of the 11 students whose semi-structured interviews were conducted were girls and five were boys.

Video blog activities consist of two basic stages. First, in the two terms before the video blog application was made, case study videos were prepared by students within the scope of the CVE course. In video blog activities, case study videos were shared, and prospective teachers were asked to watch and interpret them outside of class hours.

In order to collect quantitative data, "Attitude towards Value Education (AVE) Scale" prepared by Çetin (2018) was used in the study. This scale was applied to the control and experimental groups at the beginning and end of the CVE course. The scale includes three sub-factors and consists of 31 items under the headings of "belief in the need for values education", "internalization of value education" and "negative belief in value education". The qualitative data of the study were collected through semi-structured interviews with 11 prospective teachers who participated in video blog activities.

\section{Results}

According to ANCOVA results, it was found that there was a significant difference between the posttest scores corrected according to the AVE scale pretest scores of the control and experimental groups $(F(1,85)=40.708, p=.000)$. This finding shows that the applied experimental process (giving the teacher candidates training on using video blog in values education) causes difference in students' attitudes towards values education. In addition, it was observed that there was a significant difference in favor of posttest scores in the pre-test and posttest scores of the experimental group teacher candidates according to the factors of the AVE scale, "belief in the need for values education", "internalize 
value education" and "negative belief in value education". All participants of the semi-structured interviews stated that video blog activities had a positive effect on the CVE course. Moreover, prospective teachers commented that video blog applications make CVE lessons more memorable and interesting, and facilitate students' participation. Prospective teachers made suggestions such as making more posts on video blog, interpreting videos in lesson and expanding its application.

\section{Discussion and Suggestions}

As a result of the study, it has been observed that there is a significant difference between the attitudes of prospective teachers participating in the video blog activities carried out in the CVE course towards value education and the attitudes of the prospective teachers who study the course with traditional methods, and the attitude points of the teacher candidates participating in the video blog activities are found to be higher. Considering that the two groups performed the same practices in face-to-face lessons, it can be said that video blog activities are the source of this difference. In this positive attitude change of prospective teachers' values education, it can be shown that video blog activities are effective in values education, while it is more fun to have videos it is also more feasible because it takes values education out of limited course hours. Semi-structured interviews were also used to analyze this attitude change in teacher candidates' values education perspective. All prospective teachers stated that as a result of their video blog activities, they thought that there was a positive change in their view of values education and that values education was "more important" and "more useful".

In video blogging activities, pre-service teachers were asked to write their analysis for case study videos in the comments sections below the posts. For this practice, preservice teachers commented that "it is effective in gaining values", "offers the opportunity to get to know students better" and "enables students to interact with each other". Asking students to analyze case study videos in video blog activities is an application suitable for value analysis approach. Prospective teachers also stated that this application contributed to the values education process and increased the interaction in the classroom, and supported the interpretation of the case videos.

Another finding obtained as a result of the research was that there was a significant difference in favor of posttest scores in the pre-test and posttest scores of 
the experimental group teacher candidates according to the factors of the AVE scale, "belief in the need for values education", "internalize value education" and "negative belief in value education" factors. These results are consistent with the attitude change that occurs in prospective teachers.

Based on the results of the research, the following suggestions are presented.

- More case studies videos can be produced by professional teams and professional individuals in the field of video shooting with the contribution of academicians who are experts in value education. Although there is a lot of video content on an international scale, yet Turkish content is very limited.

- In-service trainings to be organized for working teachers and video blog activities for values education can be promoted, and teachers can be trained for the application of this method.

- Video blog events can be held together with formal education students and teachers, and data can be collected on their contribution to values education.

- According to the results obtained from the practices of video blog activities carried out in schools, difficulties experienced in the application of the method can be observed and the method can be developed in line with these results. 